$$
\begin{gathered}
\text { UNIVERSIDADE DE SÃO PAULO } \\
\text { FACULDADE DE ODONTOLOGIA DE RIBEIRÃO PRETO } \\
\text { PóS-GRADUAÇÃO EM ODONTOPEDIATRIA }
\end{gathered}
$$

AusÊnCIA dA INTERLEUCINA-22 InTERfERE NA MICROBIOTA

Bucal e na Progressão de Lesões Periapicais

Induzidas em Dentes de CAMUndongos

Katharina Morant Holanda de Oliveira 



\section{AUSÊnCIA DA INTERLEUCINA-22 INTERfERE NA MICROBIOTA Bucal e na Progressão de lesões Periapicais Induzidas em Dentes de Camundongos}

Dissertação apresentada à Faculdade de Odontologia de Ribeirão Preto da Universidade de São Paulo, para obtenção do título de Mestre em Ciências.

Programa: Odontopediatria

Área de Concentração: Odontopediatria

Orientador: Profa. Dra. Raquel Assed Bezerra da Silva

\section{VERSÃO CORRIGIDA}

Ribeirão Preto

2013 
AUTORIZO A REPRODUÇÃO E/OU DIVULGAÇÃO TOTAL OU PARCIAL DA PRESENTE OBRA, POR QUALQUER MEIO CONVENCIONAL OU ELETRÔNICO, DESDE QUE CITADA A FONTE.

Katharina Morant Holanda de Oliveira

\section{Ficha Catalográfica}

Oliveira, Katharina Morant Holanda

Ausência da Interleucina-22 Interfere na Microbiota Bucal e na Progressão de Lesões Periapicais Induzidas em Dentes de Camundongos. Ribeirão Preto, 2013.

121p. : il. ; $30 \mathrm{~cm}$

Dissertação de Mestrado apresentada à Faculdade de Odontologia de Ribeirão Preto/USP - Área de Concentração: Odontopediatria.

Orientador: Profa. Dra. Raquel Assed Bezerra da Silva

1.Interleucina-22; 2.Camundongos knockout; 3.Lesão periapical; 4.Reabsorção óssea; 5.Osteoclastos; 6.Inflamação;

7.Imunohistoquímica.

Versão corrigida da Dissertação. A versão original se encontra disponível na Biblioteca da Unidadesede do Programa 


\title{
AUSÊNCIA DA INTERLEUCINA-22 INTERfERE NA MiCROBIOTA Bucal e na Progressão de lesões Periapicais InduZidas em Dentes de CAMUndongos
}

\author{
Dissertação apresentada à Faculdade de Odontologia de \\ Ribeirão Preto da Universidade de São Paulo, para obtenção \\ do título de Mestre em Ciências. \\ Programa: Odontopediatria \\ Área de Concentração: Odontopediatria \\ Orientador: Profa. Dra. Raquel Assed Bezerra da Silva
}

Data da defesa:

\section{Banca Examinadora}

Prof. Dr.

Julgamento: Assinatura:

Prof. Dr.

Julgamento: Assinatura:

Prof. Dr.

Julgamento: Assinatura: 

Dados Curriculares

\title{
Katharina Morant Holanda De Oliveira
}

\author{
Nascimento $\quad 21$ de fevereiro de $1988-$ Recife/PE \\ Filiação Jorge Luiz Cordeiro de Oliveira \\ Maria da Penha Morant Holanda de Oliveira \\ 2006-2010 Curso de Graduação \\ Faculdade de Odontologia - UFPE \\ 2008-2009 Iniciação Científica - Bolsista CNPq \\ Universidade Federal de Pernambuco \\ 2009-2009 Curso de Atualização em Periodontia \\ Sindicato dos Odontologistas do Estado de Pernambuco \\ 2010-2011 Aperfeiçoamento em Odontopediatria \\ Centro de Pós-Graduação em Odontologia \\ 2011-2012 Aperfeiçoamento em Atendimento Odontológico a Pacientes \\ Especiais. \\ Faculdade de Odontologia de Ribeirão Preto - FORP/USP \\ 2011-2013 Curso de Especialização em Odontopediatria \\ Associação Odontológica de Ribeirão Preto - Ribeirão Preto/SP \\ 2011-2013 Curso de Pós-Graduação (Mestrado) em Odontologia \\ Área de Concentração: Odontopediatria \\ Faculdade de Odontologia de Ribeirão Preto/USP
}



"Senhor, fazei-me instrumento de vossa paz. Onde houver ódio, que eu leve o amor; Onde houver ofensa, que eu leve o perdão; Onde houver discórdia, que eu leve a união; Onde houver dúvida, que eu leve a fé; Onde houver erro, que eu leve a verdade; Onde houver desespero, que eu leve a esperança; Onde houver tristeza, que eu leve a alegria; Onde houver trevas, que eu leve a luz. Ó Mestre, Fazei que eu procure mais Consolar, que ser consolado; compreender, que ser compreendido; amar, que ser amado. Poís, é dando que se recebe, é perdoando que se é perdoado, e é morrendo que se vive para a vida eterna". 

Ofereço Esse Trabalho

Ofereço este trabalho a Deus, pai eterno, pela presença constante em minha vida. Obrigada senhor, por sempre me dar força e coragem, por todas as oportunidades maravilhosas que colocaste em meu caminho, e pelos desafios e dificuldades, que me ajudam a crescer e melhorar cada vez mais. 

Dedico esse trabalho à minha avó Maria Tereza Morant de Holanda (in memoriam), que infelizmente não está mais ao meu lado, mas tem presença constante em meus pensamentos e decisões. Obrigada por ter guiado os meus passos, e ter dedicado a sua vida a cuidar da nossa família. Agradeço todo o amor e carinho além dos ensinamentos preciosos para a vida inteira. Voinha, você sempre será o meu exemplo de vida.

Aos meus pais Jorge Luiz Cordeiro de Oliveira e Maria da Penha Morant Holanda de Oliveira, que sempre tiveram como objetivo de suas vidas a realização dos sonhos dos filhos. Obrigada por todo o esforço, paciência, disciplina, amor, carinho e sabedoria, que sempre encheram meus dias de conforto e certeza que com vocês ao meu lado conseguirei alcançar qualquer objetivo. Tenho orgulho de ser filha de vocês.

Às minhas irmãs Nathalia Morant Holanda de Oliveira e Dianna Morant Holanda de Oliveira, por todos os momentos de alegria e descontração, companheirismo e cumplicidade. Obrigada pela torcida eterna e por sempre confiarem em mim. Obrigada por sermos três e ao mesmo tempo uma só. Amo vocês.

Aos meus tios Ricardo Morant de Holanda e Romildo Morant de Holanda pelo zelo e atenção, que tantas vezes me fizeram sentir como filha ao invés de sobrinha. Obrigada por todo o carinho, apoio e incentivo.

Ao meu namorado José Ricardo Vanderlei, por todos os momentos inesquecíveis, pelo apoio constante e doses diárias de estímulo! Obrigada por acreditar tanto no meu potencial e por ter trazido paz ao meu coração! Você é uma pessoa especial na minha vida. Amo você!

À famillia de Ribeirão Preto! Tantas pessoas que me confortaram em momentos difíceis e que sempre me ajudaram a superar a distância de casa. Muito obrigada por me acolherem com tanto carinho!

Às crianças, por sempre me encantarem e representarem o motivo da minha dedicação.

A todos os familiares e amigos que sempre estiveram ao meu lado.

Devo essa conquista a todos vocês

Obrigada por tudo! 

Agradecimentos Especials

\section{À minha FAMÍLIA em Ribeirão Preto...}

\section{Janine Montenegro,}

Por ter me acolhido tão bem quando eu mais precisei! Jan, muito obrigada por ter me colocado dentro da sua casa, por toda a confiança, carinho, companhia, lições de culinária, bomsenso e honestidade! Espero que a distância nunca nos afaste.

\section{Priscilla Coutinho Romualdo,}

Minha amiga-irmã! Pela amizade sincera, pela cumplicidade, pelos incontáveis momentos de alegria e apoio nas horas dificeis. Agradeço a Deus por termos encontrado uma à outra! Obrigada por sempre ter me feito sentir como integrante da família!

\section{Mariana Nemezio,}

Mari, obrigada por todos os momentos alegres, pela companhia e por toda a confiança! É muito bom tê-la como amiga!

\section{Rachel Fernanda Matos,}

Por ter trazido ainda mais alegria ao nosso lar, pela simpatia, tranquilidade e por ser uma pessoa tão agradável e companheira! Espero que a nossa amizade só aumente!

\section{À minha famîlia em Ipuã...}

Às pessoas abençoadas da casa da Tia Rosângela, que sempre me fizeram sentir tão acolhida e querida. Muito obrigada por me incluírem no seu lar e fazerem parte dessa fase da minha vida. Obrigada por tudo!

À família do meu namorado, por permitirem que eu fizesse parte das suas vidas e por trazerem mais alegria à minha! Admiro muito a união e carinho entre vocês! 



\section{AGRADECIMENTOS}

À Universidade de São Paulo, na pessoa do atual reitor, Prof. Dr. João Grandino Rodas, e do vice-reitor, Prof. Dr. Hélio Nogueira da Cruz.

À Faculdade de Odontologia de Ribeirão Preto da Universidade de São Paulo, na pessoa do atual diretor, Prof. Dr. Valdemar Mallet da Rocha Barros, e da vice-diretora, Profa. Dra. Léa Assed Bezerra da Silva.

À Coordenação do Curso de Pós-Graduação em Odontopediatria da Faculdade de Odontologia de Ribeirão Preto da Universidade de São Paulo, na pessoa da coordenadora, Profa. Dra. Léa Assed Bezerra da Silva e do vice-coordenador Prof. Dr. Paulo Nelson Filho.

À CAPES (Coordenação de Aperfeiçoamento de Pessoal de Nível Superior), pela bolsa concedida.

Aos professores da disciplina de Odontopediatria da Faculdade de Odontologia de Ribeirão Preto da Universidade de São Paulo:

Profa. Dra. Sada Assed, por representar para mim uma fonte de inspiração na Odontopediatria.

Profa. Dra. Lea Assed Bezerra da Silva, pela oportunidade, pelos desafios propostos e a imensurāvel contribuição na minha formação profissional. Obrigada pelos ensinamentos, disponibilidade e confiança.

Prof. Dr. Paulo Nelson Filho, meu exemplo de mestre, por todas as orientações durante o período do Mestrado. Muito obrigada pela pelos ensinamentos, pela disponibilidade, paciência, apoio, incentivo, e zelo com as correções. Espero ter alcançado as suas expectativas!

Profa. Dra. Aldevina Campos de Freitas, exemplo de dedicação à profissão, pela ternura, paciência e por todos os ensinamentos transmitidos.

Profa. Dra. Raquel Assed Bezerra da Silva, minha orientadora nesse trabalho e em tantas outras questões no decorrer desses 2 anos! Muito obrigada por toda a confiança, pela oportunidade de crescimento profissional, pelo bom-humor, paciência, ensinamentos compartilhados, disponibilidade, compreensão, apoio e palavras de conforto! A senhora foi essencial para a concretização desse sonho.

Profa. Dra. Alexandra Mussolino de Queiroz, pela simpatia, pelo apoio e incentivo, e pelas palavras de elogio e conforto. Admiro a sua dedicação à Clínica de Pacientes Especiais, lugar que me inspira e encanta. 
Profa. Dra. Andiara de Rossi, por todos os ensinamentos transmitidos, pelo incentivo, apoio, paciência e disponibilidade, além de todas as contribuições nesse trabalho, sempre tão enriquecedoras. Muito obrigada, profa!

Profa. Dra. Cristina Borsatto, pela convivência tão agradável, pelos ensinamentos transmitidos e pela simpatia. Espero que possamos realizar muitas parcerias de pesquisa futuras!

Profa. Dra. Kranya Serrano, pela disponibilidade e orientação no meu primeiro estágio do Programa de Aperfeiçoamento de Ensino nesta faculdade. Obrigada pela confiança, simpatia, palavras de conforto e apoio.

Profa. Dra. Maria da Conceição Pereira Saraiva, professora da Disciplina de Epidemiologia, pos todos os ensinamentos transmitidos.

Aos professores da disciplina de Ortodontia da Faculdade de Odontologia de Ribeirão Preto da Universidade de São Paulo: Prof. Dr. Fábio Lourenço Romano, Prof. Dr. José Tarcísio Lima Ferreira, Profa. Dra. Mírian Aiko Nakane Matsumoto, Profa. Dra. Maria Bernadete Sasso Stuani, pela convivência agradável no mesmo departamento, pelas orientações e ensinamentos transmitidos.

A todos os professores convidados que tive a oportunidade de conhecer durante o curso de Mestrado, pelos conhecimentos transmitidos com tanta destreza e dedicação.

Aos Funcionários da Faculdade de Odontologia de Ribeirão Preto...

Marilia Pacífico Lucisano, por todo o apoio e paciência nas várias fases desse trabalho e durante todo o período do Mestrado. Obrigada pela disponibilidade, paciência e carinho.

Francisco Wanderlei Garcia de Paula e Silva e Carolina Paes Torres Mantovani, pela paciência, convivência agradável, ensinamentos transmitidos e auxîlio nas atividades de clínica.

Marco Antônio dos Santos, por toda a ajuda nas atividades laboratoriais, pela disponibilidade e convivência agradăvel.

Nilza Letícia Magalhães, obrigada pelo bom-humor, dedicação e paciência, solucionando sempre da melhor forma todos os imprevistos. Você é uma pessoa iluminada!

Fátima Aparecida Jacinto Daniel e Tatiana Goudromihos pela ajuda nas atividades laboratoriais, apoio e bom-humor.

Micheli Cristina Leite Rovanholo, Matheus Morelli Zanela e Filomena Leli Placciti, pela disponibilidade e atenção, pelas conversas e convivência agradável e por solucionar todos os problemas aparentemente insolucionáveis! 
Aos funcionários da Clínica de Pacientes Especiais, Benedita Viana Rodrigues, Fātima Aparecida Rizoli e Renata Aparecida Fernandes, por todo o apoio e carinho com que tratam todos os alunos e pacientes.

Aos funcionários da Clínica 1: José Aparecido Neves do Nascimento, Vera do Nascimento Scandelai e Karina Dadalt Quaglio, pela convivência agradável e pelo apoio nas atividades de clínica junto à graduação.

Aos funcionários do Biotério da Faculdade de Odontologia de Ribeirão Preto da Universidade de São Paulo, Antônio Sérgio Aparecido Mesca, Aline Aparecida Ferraresi Tiballi e Antônio Massaro, pela paciência, disposição em ajudar e por todo auxílio no cuidado com os animais.

Aos funcionários do Biotério da Faculdade de Ciências Farmacêuticas de Ribeirão Preto da Universidade de São Paulo e do Biotério de Genética da Faculdade de Medicina de Ribeirão Preto da Universidade de São Paulo, pela concessão, cuidado com os animais, disponibilidade e prestatividade.

Aos colegas da Pós-Graduação em Odontopediatria da Faculdade de Odontologia de Ribeirão Preto da Universidade de São Paulo, Ana Caroline Fumes, Ana Zilda Nazar Bérgamo, Cristina Bueno Brandão, Daniela Silva Barroso de Oliveira, Danielly Cunha Araújo Ferreira, Daniele Lucca Longo, Denise de Souza Matos, Driely Barreiros de Oliveira, Fernanda Regina Ribeiro Santos, Gabriela Cristina Sautin, Giselle de Ângelo Leite Carbonaro Guerreiro, Karina Grecca Pieroni, Késsia Suênia Fidélis de Mesquita, Letícia Andreotti Bignardi, Lidia Regina da Costa Hidalgo, Larissa Nogueira Soares Ribeiro, Marcela Cristina Damião Andrucioli, Mariana Alencar Nemezio, Marília Rodrigues Moreira, Marina Fernandes de Sena, Marta Maria Martins Giamatei Contente, Maya Arnez, Priscilla Coutinho Romualdo, Rodrigo Teixeira Macri, Silvana Polizeli, Talita Pereira Prates, Talitha de Siqueira Mellara, pelo incrivel "intercâmbio cultural", por todo o apoio, troca de experiências e pela convivência sempre tão agradável.

Às amigas de turma de mestrado, Ana Caroline Fumes, Daniele Lucca Longo, Denise de Souza Matos, Mariana Alencar Nemezio, Priscilla Coutinho Romualdo, pelo companheirismo essencial, pelo carinho, bom-humor, apoio, trocas sinceras de confissões, pelos momentos únicos e experiências maravilhosas! Com vocês aprendi diversas lições que levarei para sempre comigo. Obrigada pela amizade e confiança! Espero que a distância nunca nos afaste!

Às amigas da graduação, Fernanda de Albuquerque Almeida, Luciana Silva Regueira, Juliana Carneiro Leão, Priscylla Gonçalves Correia e Samantha Cardoso de Andrade, por terem dividido comigo 
a gratificante e árdua experiência da formação em Odontologia. Obrigada pela amizade sincera, por demonstrarem tanto apoio e carinho, mesmo à distância, e pela certeza de que sempre poderei contar com vocês!

Às amigas de infância, Gisele Cruz Camboim, Nathalia da Fonte Nogueira, Maria Juliana Godoy, Camila Guedes Cabral de Arruda, Rebeca Mattos Queiroz, Thais Torres Rodrigues, Ana Cecilia Araújo, por terem me ensinado que algumas coisas nunca mudam, e que nem o tempo nem a distância conseguem separar amizades verdadeiras. Obrigada pela união até hoje, e por serem parte da minha alegria e terapia nos momentos difíceis.

Aos meus familiares... tios, tiass, primos, avós (in memoriamm), pelo incentivo, suporte e afeto! Muito obrigada por sempre torcerem e confiarem em mim. Sem vocês esse sonho não teria se realizado.

À secretária do curso de Especialização de Ortodontia Rosemary Alves de Sá pela formatação deste trabalho.

Ao Cassio Geraldo dos Reis pela realização de parte da análise estatîstica deste trabalho.

À equipe da Clic Foto e Vídeo pela montagem das pranchas e impressão do trabalho. 


\section{RESUMO}

Oliveira, KMH. Ausência da interleucina-22 interfere na microbiota bucal e na progressão de lesões periapicais induzidas em dentes de camundongos. Ribeirão Preto, 2013. 119p. Dissertação (mestrado) - Faculdade de Odontologia de Ribeirão Preto, Universidade de São Paulo.

Introdução: O objetivo deste trabalho foi caracterizar a composição da microbiota bucal e a formação e progressão de lesões periapicais induzidas experimentalmente em dentes de camundongos knockout para IL-22 (IL-22 KO) comparados com animais wild-type (WT). Material e Métodos: Inicialmente, foi realizada a avaliação do perfil microbiano da cavidade bucal dos animais (40 espécies de micro-organismos), no dia das exposições pulpares, por meio de técnica de biologia molecular (Checkerboard DNA-DNA hybridization). Em seguida, lesões periapicais foram induzidas nos primeiros molares inferiores dos camundongos e, decorridos os períodos de 7, 21 e 42 dias, os animais foram submetidos à eutanásia em câmara de $\mathrm{CO}_{2}$. As mandíbulas foram então removidas e submetidas ao processamento histotécnico. A seguir, cortes representativos de cada dente foram corados com hematoxilina e eosina (HE), para descrição do tecido pulpar e das regiões apical e periapical, em microscopia óptica convencional e mensuração da área das lesões periapicais em microscopia de fluorescência. Além disso, cortes sequenciais foram avaliados por meio de: histoenzimologia para a marcação de osteoclastos (TRAP), coloração de Brown \& Brenn (para identificação de bactérias) e imunohistoquímica (para identificação de RANK, RANKL e OPG). Os escores da quantidade de células bacterianas, para cada uma das 40 espécies avaliadas, foram submetidos à analise estatística empregando o teste não-paramétrico de Mann-Whitney para amostras independentes, para comparação entre os grupos. Os resultados numéricos obtidos na análise morfométrica da área das lesões periapicais e do número de osteoclastos foram submetidos à análise estatística "one-way" ANOVA e pós-teste de Bonferroni. Para todas as análises foi adotado o nível de significância de 5\%. Resultados: Em relação ao perfil microbiano encontrado na cavidade bucal dos animais, foi possível observar diferença estatisticamente siginificante entre os dois grupos de animais para 6 espécies bacterianas $(p<0,05)$, sendo 5 dessas espécies mais encontradas nos animais WT e apenas 1 encontrada em maior quantidade nos animais IL-22 KO. Já em relação à análise microscópica, o grupo dos animais WT mostrou diferença estatisticamente significante entre 7 e 42 dias e entre 21 e 42 dias, com aumento progressivo no tamanho das lesões e no número de osteoclastos $(p<0,05)$. No grupo dos animais IL-22 KO, houve um aumento do tamanho da lesão e do número de osteoclastos entre 7 e 21 dias, seguido de diminuição desses parâmetros entre 21 e 42 dias, com diferença significante $(p<0,05)$ entre 7 e 21 dias. Além disso, na comparação entre os dois tipos de animais, foram encontradas diferenças significantes $(p<0,05)$ em relação ao tamanho 
das lesões periapicais e ao número de osteoclastos aos 42 dias, sem diferenças em relação à localização de bactérias e imunohistoquímica. Conclusões: Esse estudo demonstrou diferenças na composição da microbiota bucal dos animais WT e IL-22 KO, o que pode ter influenciado na formação das lesões periapicais. Além disso, a ausência da IL-22 em camundongos interferiu na progressão das lesões periapicais, assim como no número de osteoclastos, sugerindo a participação da IL-22 na resposta imune e inflamatória do hospedeiro à infecção dos canais radiculares.

Palavras-chave: Interleucina-22, camundongos knockout, lesão periapical, osteoclastos, inflamação, imunohistoquímica, micro-organismos. 


\section{ABSTRACT}

Oliveira, KMH. Absence of IL-22 interferes with the oral microbiota and the progression of induced periapical lesions in mice teeth. Ribeirão Preto, 2013. 119p. Dissertação (Mestrado) - Faculdade de Odontologia de Ribeirão Preto, Universidade de São Paulo.

Introduction: The aim of this study was to evaluate the participation of the IL-22 on the formation and progression of experimentally induced periapical lesions in teeth of IL-22 knockout (IL-22 KO) compared to wild-type (WT) mice. Methods: Initially, it was performed the evaluation of the microbial profile present in the oral cavity of animals (40 bacterial species), on the day of pulpal exposures, by means of molecular biology technique (checkerboard DNA-DNA hybridization). Then, the periapical lesions were induced in the inferior first molars of the mice and, after the periods of 7, 21 and 42 days, the animals were euthanized in a $\mathrm{CO}_{2}$ chamber. The jaws were removed and subjected to histotechnical processing. The following sections were representative stained with hematoxylin and eosin (HE) for description of the pulp tissue, apical and periapical regions in conventional optical microscopy and measurement of the area of periapical lesions in fluorescence microscopy. Moreover, sequential specimens were evaluated through: histoenzimology for osteoclasts (TRAP) Brown \& Brenn staining (for bacteria identification) and immunohistochemistry (for RANK, RANKL and OPG identification). The scores of the amount of bacterial cells, for each one of the 40 species assessed, were subjected to statistical analysis using the nonparametric Mann-Whitney test for independent samples for comparison between groups. The numerical results of the morphometric analysis of the area of the periapical lesions and the number of osteoclasts were subjected to statistical analysis oneway ANOVA and Bonferroni's post-test. For all the statistical analysis the significance level of 5\% was adopted. Results: Regarding the microbial profile found in the oral cavity of the animals, it was observed statistically siginificant differences between the two groups of animals for 6 bacterial species $(p<0.05)$, with 5 species showing higher levels in the WT group and only 1 specie found in higher levels in the IL-22 KO animals. Concerning the microscopical analysis, the group of WT mice showed a statistically significant difference between 7 and 42 days and between 21 and 42 days, with a gradual increase in the size of periapical lesions and number of osteoclasts $(p<0.05)$. In the group of IL-22 KO animals, an increase in lesion size and number of osteoclasts between 7 and 21 days was observed, followed by a decrease of these parameters between 21 and 42 days, with significant differences between 7 and 21 days $(p<0.05$ ). Moreover, when comparing the two types of animals, significant differences were found ( $p$ $<0.05$ ) about to the size of periapical lesions and number of osteoclasts at 42 days, without 
differences in localization of bacteria and immunohistochemistry. Conclusions: This study showed differences in the composition of the oral microbiota of the two types of animals that may have influenced the progression of periapical lesions. Moreover, the absence of IL-22 in mice interfered with the progression of periapical lesions, as well as in the number of osteoclasts, suggesting the involvement of this cytokine in host's immune and inflammatory response to the infection of root canals.

Key words: Interleukin-22, knockout mice, periapical lesion, osteoclasts, inflammation, immunohistochemistry, microorganisms. 
ANOVA: Análise de variância

BP: proteína ligante

BSA: Soro de albumina bovina

C57BL/6: linhagem de camundongos

CD11c+: células dendríticas

CDDH: Do inglês, Checkerboard DNA-DNA hybridization

$\mathrm{CO}_{2}$ : Gás carbônico

CXCL: quimiocina "motivo CXC"

DAB: Diaminobenzidina

DNA: Ácido Desoxirribonucleico

EDTA: etilenodiaminotetracético

FOXp3: Fator de transcrição marcador da célula Treg

GATA-3: Fator de transcrição para célula Th2

G-CSF: Fator estimulador de colônia de granulócitos

HE: coloração de hematoxilina e eosina

IFN-ץ: Interferon gama

IL: Interleucina

Kg: quilograma

KO: Do inglês, knockout

LBP: Proteína ligante de LPS

LPS: Lipopolissacarídeo

mg: miligramas

MMP: Metaloproteinase da matriz

MSX2: Fator de transcrição

NK: Células matadoras naturais

OPG: Osteoprotegerina

PBS: Solução tampão salina 
PCR: Reação de polimerase em cadeia

PGE2: Prostaglandina 2

pH: Potencial hidrogeniônico

R: Receptor

RANK: Receptor ativador do fator nuclear kappa B

RANKL: Ligante do receptor ativador do fator nuclear kappa B

RUNX2: Fator de transcrição relacionado à diferenciação osteoblástica

SPSS: Statistical Package for the Social Sciences

T үo: Células T gama delta

T-bet: Fator de transcrição específico para célula Th1

T CD4: Linfócito auxiliar

T CD8: Linfócito citotóxico

TLR: Receptor "Toll-like"

TGF- $\beta$ : Fator de crescimento transformante beta

Th: Linfócito T helper

TNF-a: Fator de necrose tumoral alfa

TRAP: Do ingles, Tartrate Resistant Acid Phosphatase-TRAP

Tregs: Células T reguladoras

WT: Do inglês, wild-type

$\mu \mathrm{m}$ : micrometro

$\mu \mathrm{L}:$ microlitro 


\section{SUMÁRIO}

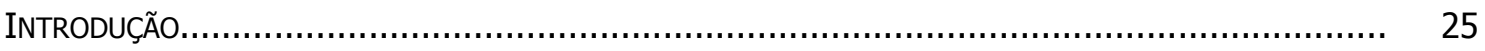

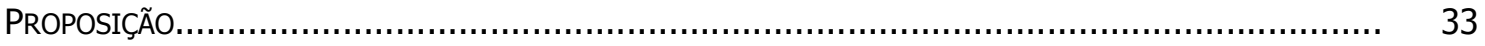

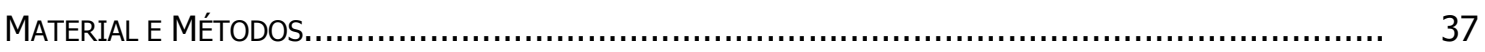

Obtenção dos Animais..................................................................................... 39

Avaliação microbiológica da cavidade bucal..................................................... 39

Indução das Lesões Periapicais.......................................................................

Processamento histotécnico e avaliação microscópica............................................ 45

Análise microscópica descritiva das regiões apical e periapical................................. 48

Morfometria em microscopia de fluorescência..................................................... 48

Histoenzimologia para a atividade da fosfatase ácida resistente ao tartarato (TRAP)... 49

Técnica de Brown \& Brenn........................................................................ 49

Imunomarcação (Imunohistoquímica)..................................................... 50

Análise Estatística............................................................................................ 51

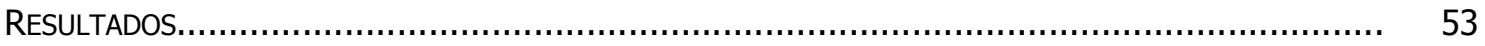

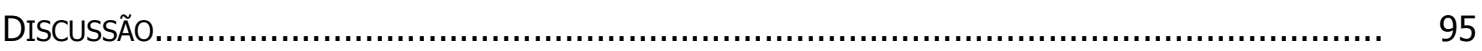

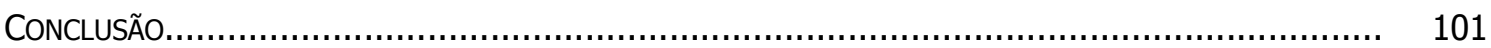

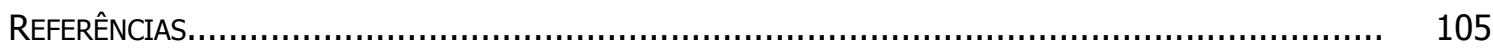

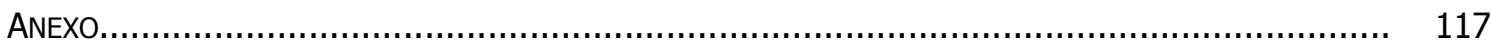



Introdução 

A invasão bacteriana no tecido pulpar desencadeia um processo inflamatório, o qual pode levar à sua necrose. A permanência desse processo resulta na instalação de uma reação infecciosa crônica, com consequente reabsorção óssea na região apical e periapical. Essa reação inflamatória envolve o recrutamento e a ativação de diferentes tipos celulares, como células endoteliais, neutrófilos polimorfonucleares, macrófagos, linfócitos e osteoclastos, tanto da resposta imune inata quanto adaptativa, resultando em osteoclastogênese e formação de uma lesão osteolítica periapical (Graves et al., 2011).

Estudos têm destacado o conceito de que a ocorrência de reabsorção óssea nas lesões periapicais envolve a resposta imune adaptativa. Em modelo roedor, destaca-se a predominância de células $T$ nessas lesões, seguidas de células $B$ e monócitos/macrófagos (Stashenko et al., 1992). A resposta estimulada pelas células $T$ inclui a participação das células Th1 (IL-2 e IFN- $y$ ), Th2 (IL-4 e IL-5), células T reguladoras (Tregs; IL-10 e TGF- $\beta$ ), Th17 (IL-17A) (Colic et al., 2009; Fukada et al., 2009), dentre outras. Além disso, fatores de transcrição essenciais para a diferenciação das células Th1, Th2, e "Tregs", T-bet, GATA-3 e FOXp3, respectivamente, foram observados em lesões periapicais (Tani et al., 1995). A importância dessa resposta imune adaptativa com o objetivo de proteger o hospedeiro durante a formação das lesões periapicais têm sido demonstrada por diferentes estudos (Wallstrom et al., 1993; Tani et al., 1995; Teles et al., 1997; De Rossi et al., 2008).

Paralelamente, as bactérias atuam nesse processo de instalação das lesões periapicais estimulando a reabsorção óssea por meio da indução da liberação de citocinas pro-inflamatórias como a IL-1ß, IL-1a, RANKL e TNF-a (Gilles et al., 1997; Jiang et al., 2002).

As interleucinas, particularmente a IL-1a e IL-1 $\beta$, são produzidas nas lesões periapicais por diferentes tipos celulares incluindo macrófagos, osteoclastos, polimorfonucleares e fibroblastos (Tani-Ishii et al., 1995; Fouad, 1997). É sabido que grande parte da atividade osteoclastogênica nas lesões periapicais ocorre em decorrência da liberação da IL-1 (Wang e Stashenko, 1993). Nesse sentido, o papel da IL-1 na destruição óssea periapical foi comprovado após a utilização de inibidores do seu receptor, que ocasionou em redução de $60 \%$ no tamanho dessas lesões (Stashenko et al., 1994). Por outro lado, quando o receptor para IL-1 é completamente bloqueado ocorre um aumento do tamanho das lesões periapicais e da morbidade (Stashenko et al., 1995), devido à atividade antibacteriana que essa citocina apresenta. Além disso, a sinalização por meio do receptor da IL-1 é essencial na prevenção da disseminação da infecção dos tecidos necróticos pulpares para os planos faciais (Graves et al., 2000).

De maneira semelhante, a expressão de TNF-a tem sido identificada na lesão periapical a partir de células como polimorfonucleares, monócitos/macrófagos e fibroblastos, 
contribuindo para a formação da lesão (Nair, 2004; De Rossi et al., 2008). A rápida destruição óssea inicial na região periapical tem sido associada, ainda, à produção de prostaglandinas, particularmente a PGE2, pela via da cicloxigenase (McNicholas et al., 1991).

Por sua vez, a IL-10 é conhecida como uma das mais importantes citocinas anti-inflamatórias e imunossupressoras, a qual apresenta principal efeito em células monocíticas e inibe a produção de IL-1ß e TNF-a (Basak e Hoffman, 2008; Sabat et al., 2010).

Recentemente descrita, a IL-22 é uma citocina pertencente à família da IL-10 (Dumountier, 2000), expressa por diferentes tipos de linfócitos, tanto do sistema imune inato como do adaptativo. Isso inclui subgrupos de células T CD4, mais notavelmente células Th17 (Zenewicz e Flavell, 2011; Chung et al., 2006; Liang et al., 2006). Além disso, esta é a principal citocina efetora das células T auxiliares Th22 (Dumoutier, 2000; Duhen et al., 2009). Paralelamente, as células Th1, células T CD8 (Wolk et al., 2002), células T ү $\delta$ (Martin et al., 2009; Siegemund et al., 2009; Sutton et al., 2009), células NK (Wolk et al., 2002; Satoh-Takayama et al., 2008; Colonna, 2009) e células CD11c+ (Zheng et al., 2008) também são capazes de produzir essa citocina. Em camundongos, os maiores produtores de IL-22 são as células Th17, podendo ser estimuladas pela presença de IL-6, IL-1 $\beta$ e TGF $\beta$ (Liang et al., 2006).

A IL-22 desempenha seu papel por meio de um complexo receptor heterodimérico composto das cadeias IL-22R1 e IL-10R2 (Xie, 2000; Kotenko, 2001). Em adição a esse complexo, há um receptor solúvel, de cadeia simples, denominado de proteína ligante da IL-22 (IL-22BP) (Wolk et al., 2004). Esta proteína regula a biodisponibilidade de IL-22, atuando como antagonista natural (Xu et al., 2001).

A IL-22 contribui para a expressão de diversas moléculas codificadoras de genes envolvidas na resposta inflamatória incluindo a IL-6, G-CSF (fator estimulador de colônia de granulócitos), IL-1a e LPS-proteína ligante, entre outras (Wolk et al., 2006b; Eyerich et al., 2009; Liang et al., 2010). Estudos demonstraram que a administração de IL22 pode contribuir na prevenção de inflamação sistêmica provocada pelo LPS presente no sangue de pacientes com Doença de Crohn por meio da indução hepática de LBP (proteína ligante de LPS) (Wolk et al., 2007).

Foi demonstrado que essa citocina atua em hepatócitos, células epiteliais, queratinócitos e fibroblatos, induzindo in vitro e in vivo uma resposta de fase aguda e estimulação da liberação de quimiocinas e MMPs (Brand et al., 2006; Wolk e Sabat, 2006a; Nickoloff, 2007; Cheng et al., 2009; Geboes et al., 2009).

Estudos recentes demonstraram que a IL-22 está envolvida na patogênese de algumas doenças autoimunes, como o lúpus eritematoso sistêmico, a esclerose sistêmica, a 
doença intestinal inflamatória e a artrite reumatóide (Nickoloff, 2007; Brand et al., 2006; Cheng et al., 2009; Geboes et al., 2009). Em estudo com artrite induzida por colágeno, por exemplo, a IL-22 apresentou papel na osteoclastogênese, levando à erosão óssea (Geboes et al., 2009).

Além disso, citocinas como TNF- $\alpha$, IL-17, IFN- $\gamma$ e IL-1 $\beta$ influenciam alguns efeitos da IL-22 (Wolk et al., 2006b). Vale destacar que as células T se diferenciam em direção ao fenótipo de Th22 na presença de algumas citocinas, como o TNF- $\alpha$ e a IL-6 (Fujita et al., 2009; Duhen et al., 2009) e, na presença da IL-1 $\beta$ e IL-6, se diferenciam em direção ao fenótipo de Th17 (Liang et al., 2006).

A natureza dual do papel, ora sinérgico, ora antagônico, desempenhado pela IL-22 está relacionada ao contexto inflamatório, que inclui a duração e acúmulo da citocina, o meio global de citocinas e o tipo de tecido envolvido (Zenewicz e Flavell, 2011). Nesse sentido, pode-se citar que embora a IL-22 promova inflamação patológica das vias aéreas, a deficiência de IL-17 nesse contexto torna a IL-22 incapaz de estimular a inflamação. Ao contrário, a IL-22 promove reparo tecidual e homeostase do epitélio das vias aéreas (Sonnenberg et al., 2011).

A IL-22 pode, ainda, agir sinergicamente com diversas outras citocinas, incluindo a IL-17A, IL-17B e TNF (Liang et al., 2006; Sonnenberg et al., 2011; Eyerich et al., 2009). A co-secreção de IL-22 com agentes proinflamatórios como o TNF-a, o IFN-ץ e/ou a IL-17 resulta em significativo aumento na reação imunoinflamatória, ao passo que a IL-22 isoladamente tem efeito protetor e de regeneração (Nograles et al., 2009; Eyerich et al., 2009). Por outro lado, estudos recentes demonstram efeitos ambíguos dessa citocina quando observada isoladamente ou na presença de outros mediadores, nos diversos processos patológicos como infecção intestinal (Stange et al., 2012), hepatite B (Feng et al., 2012), tuberculose (Cowan et al., 2012), inflamação cutânea (Cowan et al., 2012; Van Belle et al., 2012) e inflamação de vias aéreas (Takahashi et al., 2011; Nakagome et al., 2011).

Assim, destaca-se que as citocinas desempenham, por vezes, papéis sinérgicos ou antagônicos entre si, além de influenciarem na produção e liberação de outras citocinas dependendo do meio inflamatório envolvido.

Alguns autores têm proposto um duplo papel da IL-22 também contra microorganismos patogênicos, com atividade antimicrobiana principalmente nos tecidos respiratórios e intestinais além de células epidérmicas. Em 2008, Zheng et al. sugeriram que a IL-22 medeia mecanismos de defesa inata contra patógenos bacterianos na mucosa intestinal. Wolk et al., em 2004, também sugeriram papel protetor para a IL-22 contra invasões microbianas pelo aumento da imunidade inata dos tecidos. 
É importante salientar que a IL-22 está relacionada com o aumento da expressão de uma variedade de proteínas antimicrobianas em vários tecidos epiteliais, sugerindo um papel desta citocina na defesa imunitária inata, especialmente contra bactérias localizadas nos espaços extracelulares, como exposto por Aujla et al. (2008). Esses autores mostraram que a IL-22 desempenha um papel importante na infecção pulmonar por $K$. Pneumoniae, uma vez que a administração de anticorpo neutralizador da IL-22 em camundongos infectados resultou em perda da sua capacidade para controlar a infecção.

Adicionalmente, a IL-22 pode contribuir na eliminação de patógenos por meio da indução de diferentes proteínas antimicrobianas (Zheng et al., 2008).

Na Odontologia, poucos estudos avaliaram o papel da IL-22. Kato-Kogoe et al. (2012) demonstraram a presença da IL-22 e de seu receptor no ligamento periodontal de pacientes portadores de periodontite crônica moderada ou severa em contraste à sua expressão reduzida ou ausente nos tecidos gengivais. Além disso, foi observado aumento na expressão de citocinas como IL-1, IL-8 e CCL2 em células do ligamento periodontal estimuladas com IL-22 em um padrão dose-dependente. Ainda nessas células, a estimulação pela citocina IL-22 ocasionou a formação de nódulos de mineralização e induziu a expressão de genes como RUNX2, MSX2 e osteocalcina, sugerindo a participação dessa citocina na atividade de formação de matriz mineralizada.

Fibroblastos gengivais expostos a IL-22 e co-tratados com IFN-Y apresentaram expressão aumentada de CXCL10, uma quimiocina que participa do recrutamento de células $T$-helper para os tecidos lesionados, enquanto que essas mesmas células expostas à IL-22, porém co-tratadas com TNF-a, expressaram a quimiocina CXCL10 em menor intensidade. Esses resultados sugerem que um balanço de diferentes citocinas nos tecidos periodontais pode ser essencial para a produção de CXCL10 e a possível quimiotaxia de células T-helper na doença periodontal (Hosokawa et al., 2009).

Já nos tecidos periapicais, Aranha et al. (2013) relataram a presença da IL-9 e da IL-22 em granulomas, em maior quantidade nas lesões inativas do que nas ativas, de origem humana e em lesões induzidas em dentes de camundongos wild-type. Por meio da técnica de PCR (Real-Time Polymerase Chain Reaction), os autores relataram correlação positiva entre a IL-9 e IL-10, e a IL-22 e as citocinas IL-10 e TGF- $\beta$, consideradas protetoras. Esses autores destacaram também correlação inversa entre a IL-22 e a progressão da lesão nos períodos experimentais avaliados ( 0 , 3, 7, 14 e 21 dias). Assim, os autores assumem um provável papel protetor das IL-9 e IL-22 em tecidos periapicais.

Camundongos knockout são utilizados como modelo de estudo em diversas pesquisas, na tentativa de elucidar a participação de moléculas distintas no organismo, tanto 
na saúde como na doença. Estudos em diferentes áreas do conhecimento como a Endodontia e a Periodontia, entre outras, utilizam animais knockout comparando-os com animais selvagens (wild-type) (De Rossi et al., 2007B; Fukada et al., 2009; Garlet et al., 2010; Silva et al., 2012).

Assim, devido à importância dos micro-organismos e seus subprodutos na formação e progressão dos processos imuno-inflamatórios da cavidade bucal, destaca-se a necessidade de se conhecer a microbiota residente nesses animais. A análise da microbiota bucal de camundongos tem sido realizada por meio de técnicas como a cultura microbiana (Trudel et al., 1986), pirosequenciamento (Chun et al., 2010), PCR (Fardini et al., 2010), dentre outras.

Dentre as metodologias existentes, destaca-se a técnica de biologia molecular denominada Checkerboard DNA-DNA hybridization (CDDH). Esta técnica foi preconizada por Socransky et al., em 1994 e é um método que oferece vantagens em relação aos métodos tradicionais de cultura, como a detecção de micro-organismos de desenvolvimento lento, nutricionalmente exigentes/fastidiosos e, ainda, da microbiota não cultivável (Siqueira Júnior et al., 2000; Moraes et al., 2002), além de ser preciso e mais rápido que a técnica PCR, pois utiliza várias sondas de DNA de uma única vez. As amostras podem, também, ser estocadas por longos períodos de tempo (Moraes et al., 2002).

Alguns estudos têm sido realizados utilizando a técnica Checkerboard DNADNA Hybridization para a avaliação da microbiota da cavidade bucal de humanos (NelsonFilho et al., 2012; Khocht et al., 2012; Eick et al., 2013). No entanto, em camundongos, nenhum estudo foi publicado, até o momento, empregando técnicas de biologia molecular com este objetivo.

Portanto, sabendo que as lesões periapicais são processos induzidos por infecção bacteriana, originárias da cavidade bucal, e inflamação crônica, e que na sua formação e progressão estão envolvidos processos da resposta imune inata e adaptativa, a IL-22 poderia desempenhar papel importante nessas lesões. 

Proposição 

O objetivo deste trabalho foi caracterizar a microbiota da cavidade bucal, assim como a formação e progressão de lesões periapicais induzidas experimentalmente em dentes de camundongos knockout para a IL-22 (IL-22 KO) comparados com animais wildtype (WT) por meio de:

1. avaliação microbiológica da cavidade bucal dos camundongos por meio de técnica de biologia molecular Checkerboard DNA-DNA hybridization $(\mathrm{CDDH})$;

2. descrição das características do tecido pulpar e das regiões apical e periapical avaliadas por microscopia de luz convencional (coloração de hematoxilina e eosina);

3. mensuração da área microscópica correspondente às lesões periapicais em microscopia de fluorescência;

4. histoenzimologia para a marcação de osteoclastos (Tartrate Resistant Acid Phosphatase-TRAP);

5. avaliação da presença e localização de bactérias (coloração de Brown \& Brenn);

6. imunohistoquímica para a identificação de marcadores da osteoclastogênese (RANK, RANKL e OPG). 

Material Métodos 

Inicialmente, o presente projeto de pesquisa foi submetido à Comissão de Ética no Uso de Animais da Universidade de São Paulo - Campus de Ribeirão Preto, tendo sido aprovado (Processo 11.1.1403.53.5) (Anexo).

\section{Obtenção dos animais}

Foram utilizados 60 camundongos machos C57BL/6, de 6 a 8 semanas de idade, pesando em média 20 gramas, sendo 30 wild-type (WT), adquiridos do Biotério Central da Universidade de São Paulo (USP)- Campus de Ribeirão Preto e 30 camundongos knockout para a citocina IL-22 (IL-22 KO), fornecidos pelo Biotério de Genética da Faculdade de Medicina de Ribeirão Preto - USP e provenientes do Centre National de la Recherche Scientifique - CNRS (França). Todos os animais foram mantidos no biotério da Faculdade de Odontologia de Ribeirão Preto - USP com livre acesso à ração e água.

\section{Avaliação microbiológica da cavidade bucal}

Inicialmente, os camundongos foram anestesiados com ketamina (150 mg/Kg de peso corporal) e xilazina (7,5 mg/Kg de peso corporal) por meio de injeção intramuscular na coxa. Em seguida, foram imobilizados e montados numa mesa de retração da mandíbula, mantidos com a cavidade bucal aberta, para permitir a adequada visualização (Figura 1).

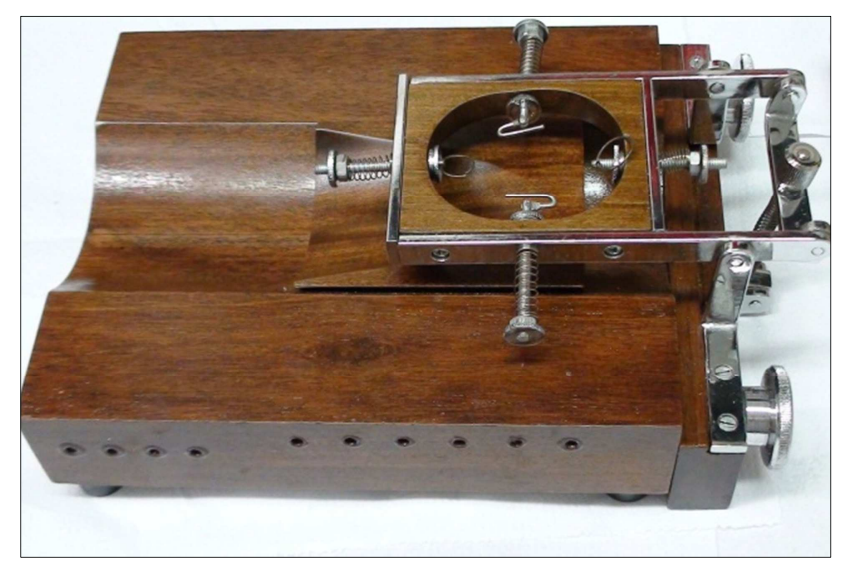

Figura 1. Mesa de retração da mandíbula especificamente confeccionada para a realização de procedimentos odontológicos em camundongos.

Para a análise da microbiota presente na cavidade de camundongos WT e IL$22 \mathrm{KO}$, amostras salivares foram obtidas com o auxílio de aplicadores descartáveis tipo microbrush (Vigodent SA Indústria e Comércio, Rio de Janeiro-RJ, Brasil) friccionados em toda a cavidade bucal, incluindo mucosa jugal, dentes, língua, tecido gengival e palato (Figura 2). 


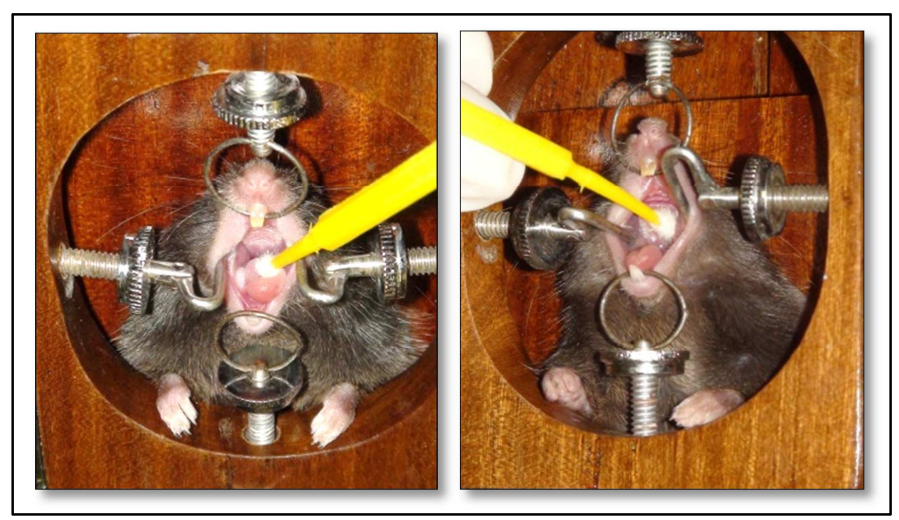

Figura 2. Camundongos imobilizados, após administração de anestesia, no momento da coleta de amostras provenientes da mucosa jugal, língua, palato e superfícies dentais.

Os aplicadores foram armazenados individualmente em tubos plásticos (Eppendorf AG Barkhausenweg, Hamburg, Alemanha), contendo $150 \mu \mathrm{L}$ da solução tampão TE (pH 7.6) e $100 \mu \mathrm{L}$ de hidróxido de sódio 0.5M (Figura 3). Em seguida, os tubos foram agitados para a dessorção microbiana na solução e armazenados em freezer à temperatura de $-20^{\circ} \mathrm{C}$ até o momento da análise. O processamento/análise das amostras foi realizado no Laboratório de Pesquisa em Odontologia II, Microbiologia, Imunologia e Biologia Molecular da Universidade de Guarulhos - SP.

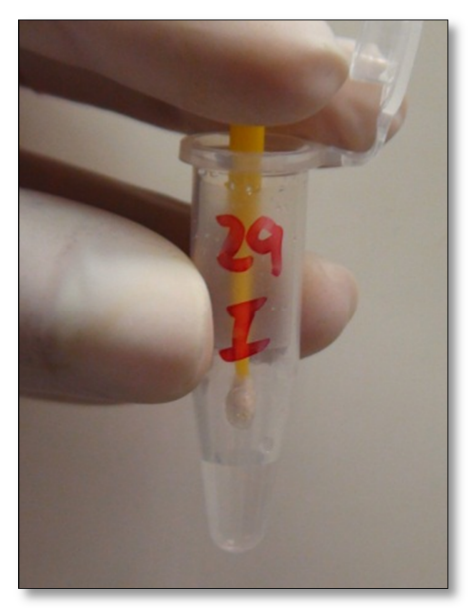

Figura 3. Aplicador do tipo microbrush sendo depositado em tubo eppendorf contendo $150 \mu \mathrm{L}$ da solução tampão $\mathrm{TE}(\mathrm{pH}$ 7.6) e $100 \mu \mathrm{L}$ de hidróxido de sódio 0.5M.

Foram selecionadas 40 cepas de bactérias, dentre as mais avaliadas e as mais prevalentes na cavidade bucal de humanos, sendo 21 Gram-negativas, 19 Gram-positivas e, quanto à tensão de oxigênio, 26 facultativas e 14 anaeróbias. As cepas foram cultivadas em anaerobiose na superfície do meio ágar-sangue, por 3 a 7 dias. Em seguida, as colônias foram raspadas e depositadas em tubos plásticos para microcentrífuga de 1,5 $\mathrm{mL}$ contendo 1 $\mathrm{mL}$ de solução TE $(\mathrm{pH} 7,6)$. As células foram lavadas 2 vezes por centrifugação na solução- 
tampão de TE por 10 minutos. O sedimento bacteriano foi então lisado em $150 \mu \mathrm{L}$ de uma solução enzimática contendo $15 \mathrm{mg} / \mathrm{mL}$ de lisozima (Sigma) e $5 \mathrm{mg} / \mathrm{mL}$ de acromopeptidase (Sigma) em solução tampão TE (pH 8,0). Posteriormente, o DNA foi isolado e purificado como descrito por Smith et al. (1989). As sondas genômicas foram preparadas para cada uma das espécies selecionadas pela marcação de $1 \mu \mathrm{g}$ do DNA bacteriano com digoxigenina, por meio do Random primer digoxigenin labeling kit (Roche Diagnostics, Indianápolis, IN, EUA), de acordo com o método descrito por Feinberg e Vogelstein (1983).

Tabela 1. Relação de micro-organismos avaliados (Checkerboard DNA-DNA hybridization)

\begin{tabular}{|c|c|c|c|}
\hline Espécie bacteriana & Procedência da cepa & Morfotipo & Fisiologia \\
\hline Actinobacillus actinomycetencomytans & $43718+29523$ & Bastonete Gram-negativo & Facultativo \\
\hline Actinomyces gerencseriae & ATCC 23860 & Bastonete Gram-positivo & Facultativo \\
\hline Actinomyces naes/undii & ATCC 12104 & Bastonete Gram-positivo & Facultativo \\
\hline Actinomyces odontolyticus I & ATCC 17929 & Bastonete Gram-positivo & Facultativo \\
\hline Actinomyces oris & ATCC 43146 & Bastonete Gram-positivo & Facultativo \\
\hline Campylobater rectus & ATCC 33238 & Bastonete Gram-negativo & Facultativo \\
\hline Capnocytophaga gingivalis & ATCC 33624 & Bastonete Gram-negativo & Facultativo \\
\hline Campylobacter gracilis & ATCC 33236 & Bacilo Gram-negativo & Facultativo \\
\hline Capnocytophaga ochracea & ATCC 33596 & Bastonete Gram-negativo & Facultativo \\
\hline Capnocytophaga sputigena & ATCC 33612 & Bastonete Gram-negativo & Facultativo \\
\hline Corynebacterium matruchotti & 14266 & Bacilo Gram-positivo & Facultativo \\
\hline Eubacterium nodatum & ATCC 33099 & Bastonete Gram-positivo & Anaeróbio \\
\hline Escherichia coli & 10799 & Bacilo Gram-negativo & Facultativo \\
\hline Enterococcus faecallis & 29212 & Coco Gram-positivo & Facultativo \\
\hline Enterococcus faecium & 6569 & Coco Gram-positivo & Facultativo \\
\hline Fusobacterium nucleatum (sp. nucleatum) & ATCC 25586 & Bastonete Gram-negativo & Anaeróbio \\
\hline $\begin{array}{l}\text { Fusobacterium nucleatum (sp. } \\
\text { polymorphum) }\end{array}$ & ATCC 10953 & Bastonete Gram-negativo & Anaeróbio \\
\hline Fusobacterium nucleatum (sp. vincentii) & 49256 & Bastonete Gram-negativo & Anaeróbio \\
\hline Fusobacterium periodonticum & ATCC 33693 & Bastonete Gram-negativo & Anaeróbio \\
\hline Haemophilus influenzae & 33533 & Cocobacilo Gram-negativo & Facultativo \\
\hline Helicobacter pylori & 43504 & Bastonete Gram-negativo & Facultativo \\
\hline Leptotrichia buccalis & 14201 & Bacilo Gram-negativo & Anaeróbio \\
\hline Porphyromonas gingivalis & 33277 & Bastonete Gram-negativo & Anaeróbio \\
\hline Prevotella intermedia & ATCC 25611 & Bacilo Gram-negativo & Anaeróbio \\
\hline Prevotella melaninogenica & ATCC 25845 & Bastonete Gram-negativo & Anaeróbio \\
\hline Propionybacterium acnes & ATCC $11827+11828$ & Bastonete Gram-positivo & Facultativo \\
\hline Streptococcus anginosus & 33397 & Coco Gram-positivo & Facultativo \\
\hline Streptococcus constellatus & 27823 & Coco Gram-positivo & Anaeróbio \\
\hline Streptococcus gordonii & ATCC 10558 & Coco Gram-positivo & Facultativo \\
\hline Streptococcus intermedius & ATCC 27335 & Coco Gram-positivo & Facultativo \\
\hline Streptococcus mitis & 49456 & Coco Gram-positivo & Facultativo \\
\hline Streptococcus mutans & 25175 & Coco Gram-positivo & Facultativo \\
\hline Streptococcus oralis & ATCC 35037 & Coco Gram-positivo & Facultativo \\
\hline Streptococcus sanguinis & ATCC 10556 & Coco Gram-positivo & Facultativo \\
\hline Streptococcus sobrinus & 33748 & Coco Gram-positivo & Facultativo \\
\hline Streptococcus pneumonia & 49619 & Coco Gram-positivo & Facultativo \\
\hline Tannerella forsythia & ATCC 43037 & Bastonete Gram-negativo & Anaeróbio \\
\hline Treponema denticola & $\mathrm{B} 1 \dagger$ & Espiroqueta Gram-negativo & Anaeróbio \\
\hline Treponema Socranskii & $\mathrm{S} 1 \mathrm{t}$ & Espiroqueta Gram-negativo & Anaeróbio \\
\hline Veillonella parvula & 10790 & Coco Gram-negativo & Anaeróbio \\
\hline
\end{tabular}

t The Forsyth Institute, Boston, MA

ATCC: American Type Culture Colection

As amostras foram avaliadas por meio da técnica Checkerboard DNA-DNA Hybridization, preconizada por Socransky et al., em 1994. Para a realização dessa técnica, as 
suspensões contidas nos tubos plásticos foram inicialmente fervidas em banho-maria por 10

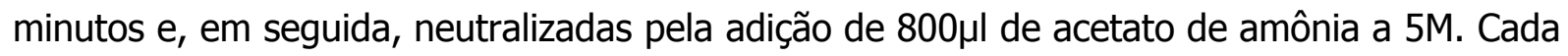
suspensão contendo o DNA livre das bactérias presentes nas amostras foi depositada em uma das canaletas do aparelho Minislot 30 (Immunetics, Cambridge, MA, EUA) (Figura 4) e transferida para uma membrana de nylon $(15 \times 15 \mathrm{~cm})$ com carga positiva (Boehringer Mannheim, Indianápolis, IN, USA). As duas últimas das 30 canaletas horizontais do Minislot foram utilizadas para a colocação dos controles, contendo uma mistura das espécies de micro-organismos investigados pelas sondas, nas concentrações correspondentes a $10^{5}$ e $10^{6}$ células, ou seja, $1 \mathrm{ng}$ e $10 \mathrm{ng}$ de DNA de cada espécie, respectivamente. A membrana foi então removida do Minislot 30 e o DNA nela concentrado foi fixado por aquecimento em forno a $120^{\circ} \mathrm{C}$ por 20 minutos.

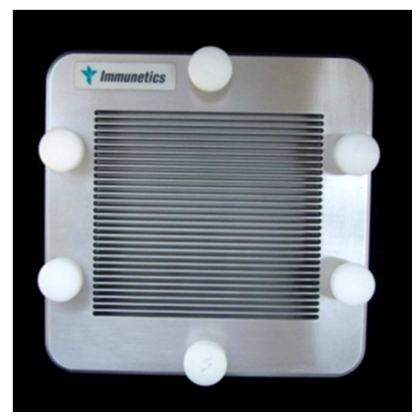

Figura 4. Aparelho Minislot 30 (Immunetics, Cambridge, MA, EUA).

A membrana foi pré-hibridada a $42^{\circ} \mathrm{C}$, por 1 hora, em uma solução contendo $50 \%$ formamida (Vetec Química Fina Ltda, Rio de Janeiro, RJ, Brasil), 1\% caseína (Vetec), 5 x solução salina citratada (SSC) $[1$ x SSC= $150 \mathrm{mM} \mathrm{NaCl}$ (Vetec), 15 M de citrato de sódio (J.T. Baker, Edo. de Méx., México), pH 7,0], 25 mM de fosfato de sódio ( $\mathrm{Na}_{2} \mathrm{HPO}_{4}$, Labsynth) $\mathrm{pH} 6,5$ e 0,5 mg/ml de RNA de levedura (Sigma).

Em seguida a membrana foi posicionada no Miniblotter 45 (Immunetics, Cambridge, MA, EUA) com as linhas contendo o DNA das amostras e dos controles posicionadas de maneira perpendicular às canaletas do equipamento. Em cada canaleta do Miniblotter 45 foi adicionada uma sonda de DNA, diluída a aproximadamente $20 \mathrm{ng} / \mathrm{mL}$, em $130 \mu \mathrm{L}$ de solução de hibridação composta de $45 \%$ formamida, $5 \times \mathrm{SSC}, 20 \mathrm{mM}$ de $\mathrm{Na}_{2} \mathrm{HPO}_{4}$

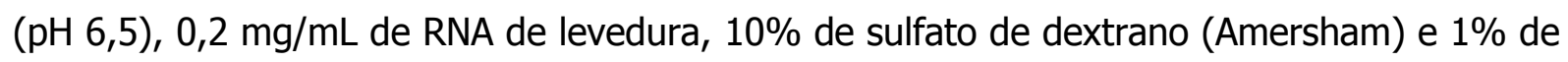
caseína. Para a hibridação, foi aguardado um período mínimo de 20 horas, a $42^{\circ} \mathrm{C}$.

Após o período de hibridação, a membrana foi removida do Miniblotter 45, lavada por 40 minutos a $65^{\circ} \mathrm{C}$ numa solução de alta adstringência (solução tampão SSC a $0,4 \mathrm{M}$ ) composta por $1 \%$ de SDS, $1 \mathrm{mM}$ de EDTA e $20 \mathrm{mM}$ de $\mathrm{Na}_{2} \mathrm{HPO}_{4}$, a fim de remover 
sondas que não hibridizaram completamente. Em seguida, a membrana foi imersa por 1 hora em uma solução contendo $1 \%$ de ácido maléico $\left(\mathrm{C}_{4} \mathrm{H}_{4} \mathrm{O}_{4}\right.$, Vetec), $3 \mathrm{M} \mathrm{NaCl}, 0,2 \mathrm{M} \mathrm{NaOH}$ (Labsynth), 0,3\% Tween 20 (Vetec), 0,5\% caseína, pH 8,0, e, em seguida, por 30 minutos, na mesma solução contendo o anticorpo anti-digoxigenina conjugado à fosfatase alcalina (Roche) em uma concentração de 1:10.000. A membrana foi, então, lavada 2 vezes, por 20 minutos, em uma solução de 0,1 $\mathrm{M}$ de ácido maléico, $3 \mathrm{M}$ de $\mathrm{NaCl}, 0,2 \mathrm{M}$ de $\mathrm{NaOH}, 0,3 \%$ de Tween 20, pH 8,0, e 1 vez, por 5 minutos, em uma solução de 0,1 M de Tris $\mathrm{HCl}$ e 0,1 M de $\mathrm{NaCl}, \mathrm{pH}$ 9,5.

Para a detecção dos sinais de quimioluminescência a membrana foi incubada por 45 minutos a $37^{\circ} \mathrm{C}$ em uma solução detectora contendo substrato para fosfatase alcalina, CDP-Star ${ }^{T M}$ Detection Reagent (Amersham). Em seguida, a membrana foi colocada em um cassete de autoradiografia (Chassi Radiográfico 30 x 40 cm, Konex, São Paulo, SP, Brasil), sobre um filme radiográfico de $18 \times 24 \mathrm{~cm}$ (Agfa Gevaert, NV, Bélgica) por, aproximadamente, 40 minutos (Figura 5). O filme foi revelado manualmente pelo método convencional tempo-temperatura, de acordo com orientações do fabricante, empregando soluções Kodak (Kodak Brasileira Com. e Ind. Ltda, São José dos Campos, SP, Brasil), mantidas à temperatura de $20^{\circ} \mathrm{C}$.

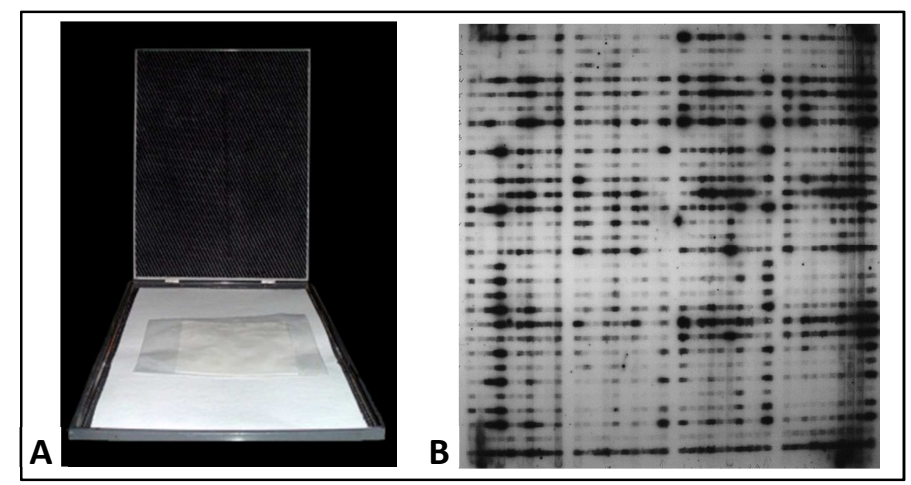

Figura 5. Membrana colocada em um cassete de $\mathrm{Rx}$, sobre um filme radiográfico, para revelação $(A)$ e obtenção dos sinais de quimioluminescência (B).

Desta forma, foi obtido um filme radiográfico com os sinais de quimiolumenescência detectados pelas sondas de DNA, onde as linhas horizontais representam as amostras e as verticais as sondas de DNA, propiciando um formato de "tabuleiro de xadrez" (Figura 6). 


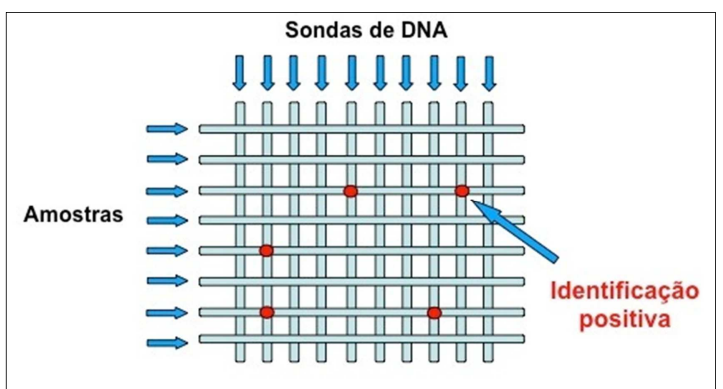

Figura 6. Representação esquemática do padrão de hibridação entre os micro-organismos das amostras e as sondas de DNA.

A leitura dos filmes radiográficos foi realizada por um único examinador calibrado (Kappa>0,8) e cego com relação aos grupos avaliados. A leitura foi realizada 2 vezes, em dias diferentes, para conferência dos resultados. Quando as leituras não foram coincidentes, foi realizada uma terceira leitura para aquela amostra não coincidente. A intensidade de cada sinal produzido por uma determinada sonda na suspensão microbiana oriunda das amostras foi comparada ao sinal produzido pela mesma sonda nas 2 linhas de controles contendo $10^{5}$ e $10^{6}$ bactérias.

A fim de facilitar a anotação dos resultados em fichas elaboradas especificamente para esse fim, foram empregados os seguintes escores:

- Escore 0: quando não havia detecção de sinal de quimioluminescência;

- Escore 1: quando observado sinal menos intenso que $10^{5}$ células;

- Escore 2: sinal equivalente a $10^{5}$ células;

- Escore 3: sinal entre $10^{5}$ e $10^{6}$ células;

- Escore 4: sinal equivalente a $10^{6}$ células; e

- Escore 5 : sinal equivalente a mais de $10^{6}$ células.

Os dados obtidos foram expressos em porcentagem de amostras positivas para cada uma das bactérias avaliadas.

\section{Indução das lesões periapicais}

Um modelo clássico para indução de lesão periapical em roedores foi empregado (Kawashima e Stashenko, 1999; Sasaki et al., 2004; De Rossi et al., 2008; Silva et al., 2012).

Após acesso à coroa dental, os tecidos pulpares dos molares inferiores dos animais de ambos os grupos (WT e IL-22 KO) foram expostos à cavidade bucal com auxílio de broca dental esférica em baixa rotação ( $n^{\circ}$ 1/4 - KG Sorensen) acoplada a peça de mão elétrica montada em motor de baixa rotação e contra-ângulo (Dabi Atlante Equipamentos Odontológicos) até que a entrada de acesso aos canais radiculares fosse visualizada e 
verificada com uma lima endodôntica tipo K número 8 (Maillefer S/A, Suíça) (Figura 7). Em seguida, os dentes permaneceram expostos à microbiota bucal (Balto et al., 2001; Sasaki et al., 2004; De Rossi et al., 2007b; Silva et al., 2012). Como controle adicional, foram utilizados dentes sem exposição pulpar.

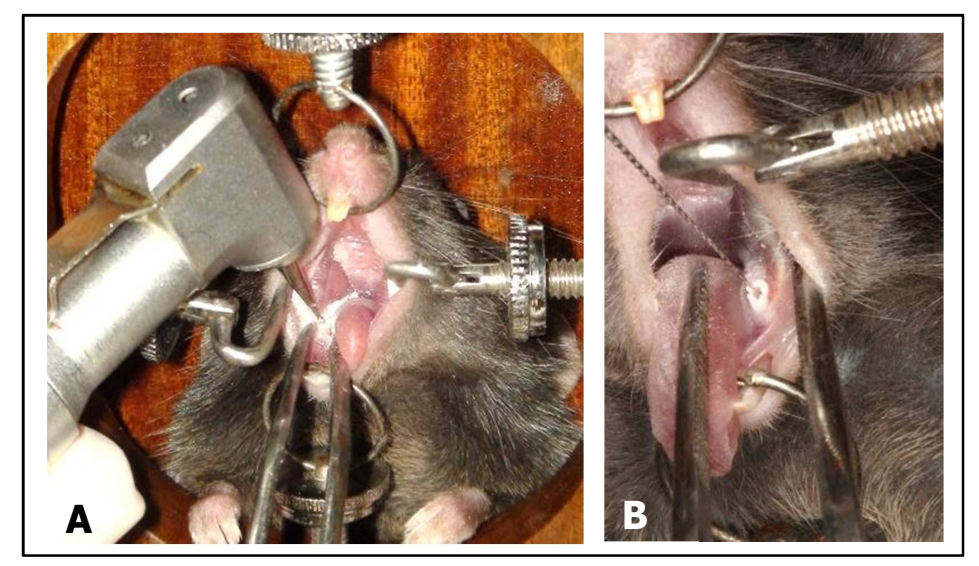

Figura 7. Abertura coronária dos primeiros molares inferiores com broca esférica em baixa rotação $(A)$ até que a entrada de acesso aos canais radiculares fosse visualizada e verificada com uma lima endodôntica tipo $\mathrm{K}$ número 8 (B).

Após os períodos experimentais de 7, 21 e 42 dias, os animais foram submetidos à eutanásia em câmara de $\mathrm{CO}_{2}$. Deve-se ressaltar que alguns animais morreram durante o período experimental, ou as peças obtidas ao final dos períodos avaliados não permitiram correto processamento e avaliação. Assim, a tabela 2 apresenta a distribuição dos grupos após a eutanásia de todos os animais.

Tabela 2. Distribuição dos grupos experimentais

\begin{tabular}{c|cc} 
Período & WT & KO \\
\hline $\mathbf{7}$ dias & 8 animais (16 dentes) & 10 animais (20 dentes) \\
\hline 21 dias & 10 animais (20 dentes) & 9 animais (18 dentes) \\
\hline 42 dias & 10 animais (20 dentes) & 9 animais (18 dentes) \\
\hline
\end{tabular}

\section{Processamento histotécnico e avaliação microscópica}

Após a eutanásia dos animais, as mandíbulas foram removidas com tesoura cirúrgica esterilizada, fixadas por imersão em formol tamponado a $10 \%$ por 24 horas à temperatura ambiente e, em seguida, lavadas por, aproximadamente, 4 horas em água corrente. Em seguida, para a descalcificação das peças, foi utilizada solução à base de EDTA a 4,13\% ( $\mathrm{pH} \mathrm{7-7,4).} \mathrm{As} \mathrm{peças} \mathrm{foram} \mathrm{mantidas} \mathrm{nesta} \mathrm{solução,} \mathrm{à} \mathrm{temperatura} \mathrm{ambiente,}$ trocada semanalmente, até sua completa descalcificação, que ocorreu, aproximadamente, após 30 dias. 0 grau de descalcificação das estruturas mineralizadas foi testado por meio da 
penetração de uma agulha nos tecidos, para verificação da sua consistência. Após esse procedimento, as peças foram submetidas ao processamento histotécnico de rotina, sendo lavadas em água corrente por 2 horas, desidratadas em álcool de concentrações crescentes ( $70 \%$ e $95 \%$ por 30 minutos cada; 2 trocas de $100 \%$ por 20 minutos cada e 2 trocas de álcool $100 \%$ por 40 minutos cada), diafanizadas em xilol (2 banhos de 20 minutos e 1 de 40 minutos) e incluídas em parafina. Os blocos contendo os dentes foram cortados longitudinalmente em micrótomo (Leica RM2145; Leica Microsystems GmbH, Wetzlar, Alemanha) no sentido mésio-distal. Cortes semi-seriados de $5 \mu \mathrm{m}$, com intervalos de $15 \mu \mathrm{m}$, foram obtidos em toda a extensão da lesão periapical, exceto na região do forame apical, onde todos os cortes foram coletados sem intervalos. Por amostra, foram obtidas de 15 a 22 lâminas, com 2 cortes em cada lâmina. A Figura 8 esquematiza as etapas de indução da lesão periapical e do processamento histotécnico. 


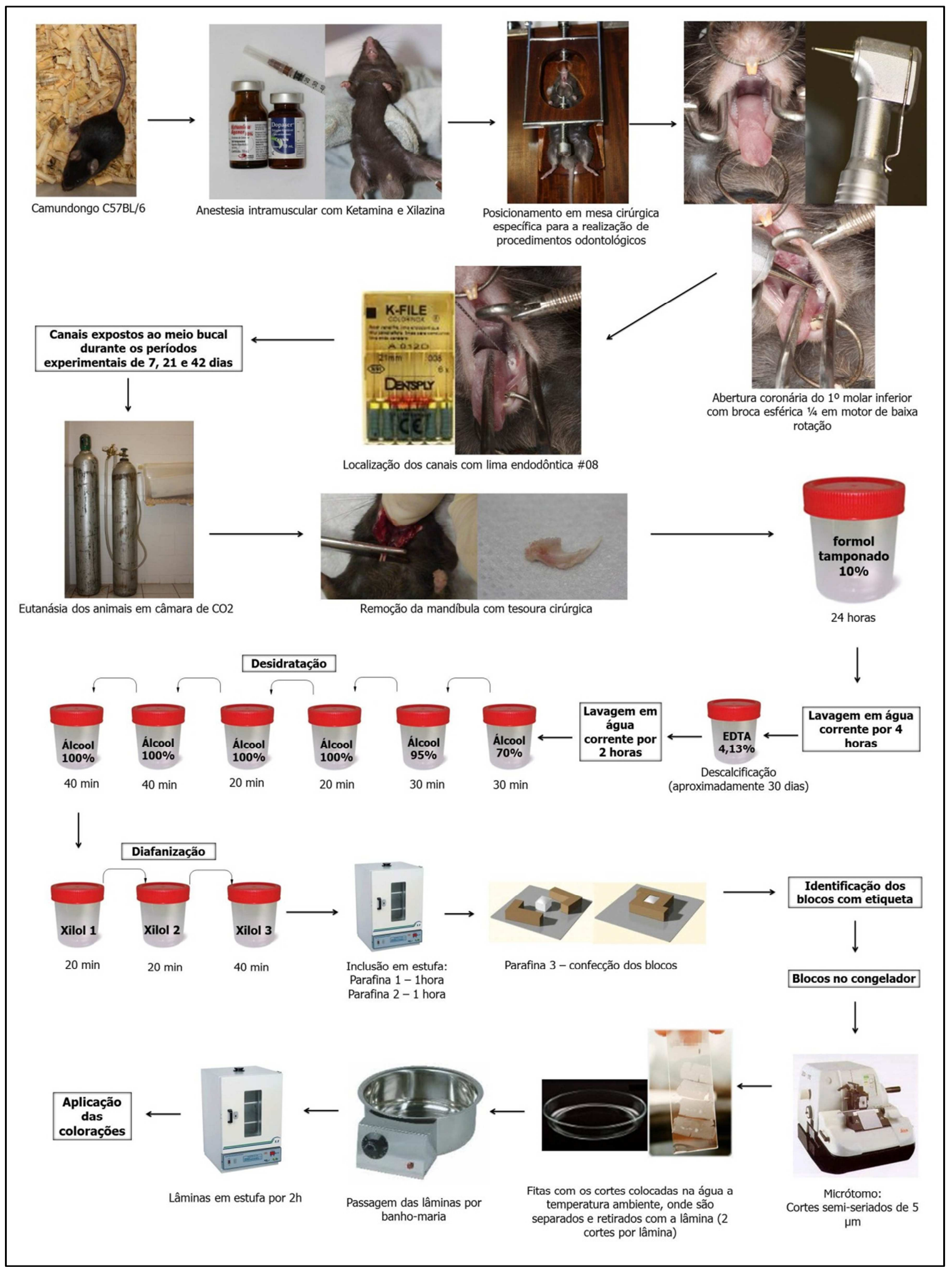

Figura 8. Fluxograma representativo das etapas de indução da lesão periapical e processamento histotécnico. 
Inicialmente, os cortes representativos de cada grupo experimental foram corados com hematoxilina e eosina $(\mathrm{HE})$ e submetidos à análise em microscopia óptica convencional, para descrição do tecido pulpar e das regiões apical e periapical. Paralelamente, foi realizada a análise morfométrica da extensão da área das lesões periapicais, em microscopia de fluorescência. Em seguida, espécimes sequenciais foram avaliados por meio de histoenzimologia para a atividade da TRAP, para identificação de osteoclastos, coloração de Brown \& Brenn para avaliação da presença e localização de bactérias e imunohistoquímica para avaliação dos marcadores da osteoclastogênese (RANK, RANKL e OPG).

Todas as análises foram realizadas no microscópio Axio Imager.M1 (Carl Zeiss MicroImaging $\mathrm{GmbH}$, Göttingen, Alemanha), com câmera AxioCam MRc5 acoplada (Carl Zeiss MicroImaging $\mathrm{GmbH}$, Göttingen, Alemanha). As análises foram realizadas apenas nas raízes distais dos primeiros molares inferiores, em cortes mostrando simultaneamente os terços coronário, médio e apical do canal radicular, o forame apical e o osso alveolar. Todas as análises foram realizadas por um único avaliador experiente, sem conhecimento prévio do grupo que estava sendo analisado.

\section{Análise microscópica descritiva do canal radicular e das regiões apical e periapical}

A análise descritiva do canal radicular e das regiões apical e periapical foi realizada nos cortes representativos de cada período e de cada grupo experimental:

- Tecido pulpar: grau de necrose (total ou parcial);

- Cemento apical: características das lacunas e o seu conteúdo (vazias ou contendo restos necróticos) e da superfície (regular ou irregular);

- Ligamento periodontal: extensão (normal ou aumentado), característica do infiltrado celular inflamatório, presença de edema e de fibras colágenas;

- Osso alveolar: ausência/presença de reabsorção.

\section{Morfometria em microscopia de fluorescência}

Conforme descrito por De Rossi et al. (2007a), a avaliação morfométrica das lesões periapicais foi realizada nos espécimes corados com HE utilizando o microscópio Axio Imager.M1, em aumento de 10x, operando no modo fluorescente, filtro Alexa Fluor 488 (AF488) com as seguintes características: excitação de G365, refletores FT395 e emissão LP420. Para cada espécime, a área da lesão periapical foi delineada e medida em $\mu \mathrm{m}^{2}$. A delimitação da lesão excluiu as estruturas intactas (ligamento periodontal, cemento e osso alveolar), facilmente identificadas pela forte fluorescência verde, assim como incluiu áreas de reabsorção e infiltrado inflamatório, identificadas pela ausência de fluorescência e aparência escurecida. 


\section{Histoenzimologia para a atividade da fosfatase ácida resistente ao tartarato (TRAP)}

A atividade da TRAP foi utilizada para a marcação de células gigantes multinucleadas. Os cortes foram desparafinizados ( 2 banhos de xilol de 5 minutos cada) e hidratados (álcool 100\% por duas vezes de cinco minutos cada; alcoóis 95\%,70\% e 50\% por dois minutos cada e água destilada pelo mesmo período). A seguir, as lâminas foram colocadas em solução de álcool/acetona $50 \%$ durante um minuto e os cortes secos à temperatura ambiente. Em seguida, uma solução contendo $10 \mathrm{ml}$ de tampão de ácido acético, 0,1 $\mathrm{ml}$ de dimetilformamida, $5 \mathrm{mg}$ de Fast-red e $1 \mathrm{mg}$ de ácido fosfórico naftol AS-BI (Sigma-Aldrich Corporation, Saint Louis, EUA) foi pipetada sobre os cortes, que foram mantidos protegidos da luz, em estufa a $37^{\circ} \mathrm{C}$, pelo tempo suficiente para se observar a marcação. Após a incubação, foi realizada a contra-coloração com azul de anilina por um minuto. A seguir, as lâminas foram montadas e avaliadas no microscópio Axio Imager.M1 sob luz convencional para contagem do número de células TRAP-positivas presentes em lacunas de reabsorção, em contato direto com o osso alveolar ao redor da lesão periapical, sendo expressas em número de células.

\section{Técnica de Brown \& Brenn}

Inicialmente, os cortes foram desparafinizados (3 banhos de xilol de 8 minutos cada), hidratados (banhos com alcoóis a 100, 95 e 80\%), lavados em água corrente por, aproximadamente, 3 minutos, e colocados em um recipiente com água destilada. A solução de violeta cristal tamponada com bicarbonato de sódio a $5 \%$ foi aplicada sobre os cortes por 30 segundos e, em seguida, as lâminas foram lavadas em água destilada. A seguir, as lâminas foram mergulhadas em solução de iodo de Gram por 1 minuto e lavadas em água destilada. Após a remoção do excesso de água destilada com papel absorvente, as lâminas passaram por uma solução de éter-acetona (proporção 1:1) para remoção do excesso de corantes, e, novamente, lavadas em água destilada. Em seguida, as lâminas foram colocadas em fucsina básica, durante 1 minuto, lavadas em água destilada, colocadas em ácido pícrico aquoso, por 1 minuto, lavadas e secas com papel absorvente (Brown e Brenn, 1931). Posteriormente, as lâminas foram mergulhadas em solução de acetona P.A., para remoção do excesso de corantes, e em solução de acetona-xilol. A seguir, foi realizada a diafanização, desidratação e montagem das lâminas com lamínula e entellan.

Essa coloração foi utilizada para avaliar a presença ou ausência de bactérias e sua localização na coroa do dente, no sistema de canais radiculares e nos tecidos periapicais 
(cemento, ligamento periodontal e osso alveolar). Para esta avaliação foram atribuídos escores de 0 a 5 (De Rossi et al., 2008), como descrito a seguir:

- Escore 0: Ausência de bactérias;

- Escore 1: Presença de bactérias na coroa do dente;

- Escore 2: Presença de bactérias no terço cervical do canal radicular;

- Escore 3: Presença de bactérias no terço médio do canal radicular;

- Escore 4: Presença de bactérias no terço apical do canal radicular;

- Escore 5: Presença de bactérias na lesão periapical.

Os dados obtidos foram expressos em porcentagem da ocorrência de cada um dos escores.

\section{Imunomarcação (Imunohistoquímica)}

As reações de imunohistoquímica foram realizadas por meio da técnica da imunoperoxidase. Os cortes histológicos foram desparafinizados, sendo os epítopos antigênicos recuperados com calor utilizando tampão citrato $(\mathrm{pH}=6,0)$ em forno de microondas (duas vezes de 10 segundos). Após retornarem à temperatura ambiente, as lâminas foram lavadas 2 vezes por 10 minutos com PBS e 1 vez com solução PBS/Triton (Sigma-Aldrich Corporation, Saint Louis, EUA) 0,5\% pelo mesmo período. O bloqueio da peroxidase endógena foi realizado com peróxido de hidrogênio a $3 \%$ por 20 minutos. A seguir, as lâminas foram novamente lavadas com PBS e PBS/Triton conforme descrito anteriormente. O bloqueio das ligações inespecíficas foi realizado com solução de $1 \%$ BSA (albumina de soro bovino)/PBS por 30 minutos. A seguir, as lâminas foram incubadas overnight em geladeira com os anticorpos primários diluídos em BSA 1\%: anti-RANK (polyclonal rabbit antibody H300 sc:9072; Santa Cruz Biotechnology Inc.; diluído 1:700), anti-RANKL (polyclonal goat antibody n-19 sc:7628; Santa Cruz Biotechnology Inc.; diluído 1:400); anti-OPG (polyclonal goat antibody n-20 sc:8468; Santa Cruz Biotechnology Inc.; diluído 1:700).

Os anticorpos primários e secundários específicos foram utilizados para identificação de marcadores da osteoclastogênese (RANK, RANKL e OPG).

Após retornarem à temperatura ambiente, as lâminas foram lavadas como previamente descrito e incubadas com anticorpo secundário biotinilado (goat anti-rabbit IgGB sc-2040 e rabbit anti-goat IgG-B sc-2774; Santa Cruz Biotechnology Inc., diluídos 1:200), por 1 hora à temperatura ambiente. Depois de nova lavagem, foi colocado o complexo avidina-biotina-peroxidase (ABC kit, Vecstain; Vector Laboratories Inc.) por 30 minutos. A seguir, as lâminas foram novamente lavadas com PBS e PBS/Triton e foi efetuada a 
revelação da reação com solução de diaminobenzidina (DAB; Sigma-Aldrich Corporation, Saint Louis, EUA) e $\mathrm{H}_{2} \mathrm{O}_{2}$ a $3 \%$ em PBS por 1 minuto. As lâminas foram contra-coradas com Hematoxilina de Harris por 10 segundos, lavadas em água corrente, lavadas em água amoniacal por 30 segundos, lavadas em água corrente, diafanizadas, desidratadas e montadas. A análise foi realizada em microscópio Axio Imager.M1 sob luz convencional.

Os dados foram expressos de forma qualitativa de acordo com a presença e localização das marcações.

\section{Análise Estatística}

Os escores da quantidade de células bacterianas presentes na cavidade bucal foram submetidos à analise estatística por meio do programa SPSS, empregando o teste não-paramétrico de Mann-Whitney para amostras independentes, para comparação entre os grupos. Os resultados numéricos obtidos da análise morfométrica da área das lesões periapicais e do número de osteoclastos foram submetidos à análise estatística one way ANOVA e pós-teste de Bonferroni, utilizando o software Graph Pad Prism 4.0 (Graph Pad Software Inc, San Diego, CA, EUA). Para todas as análises foi adotado o nível de significância de $5 \%$. 

Resultados 



\section{Avaliação microbiológica da cavidade bucal}

Após análise dos dados obtidos, foi possível observar que, das 40 espécies bacterianas avaliadas, todas estavam presentes na cavidade bucal dos camundongos WT. Já para os animais IL-22 KO, apenas a Porphyromonas gingivalis estava ausente.

Nos camundongos WT, as espécies mais prevalentes foram Actinomyces oris $(93,3 \%)$, Treponema denticola $(86,6 \%)$, Capnocytophaga ochracea $(80 \%)$, Streptococcus gordonii (80\%), Streptococcus sobrinus (80\%) e Tannerella forsythia (80\%), e as menos prevalentes foram Propionybacterium acnes (20\%) e Fusobacterium periodonticum (13,3\%), sem predominância em relação à classificação de Gram ou à tensão de oxigênio.

Já para os animais IL-22 KO, as espécies mais prevalentes foram Treponema denticola (100\%), Campylobacter gracilis (93,3\%), Capnocytophaga ochracea (93,3\%), Prevotella intermedia (93,3\%), Streptococcus oralis (86,6\%) e Capnocytophaga gingivalis $(86,6 \%)$, com relativa predominância de micro-organismos Gram-negativos e variabilidade em relação à tensão de oxigênio.

$\mathrm{Na}$ comparação entre os 2 grupos de animais, foi observada diferença estatisticamente significante para as seguintes espécies: Actinomyces naes/undii, Porphyromonas gingivalis, Streptococcus sobrinus, Veillonella parvula, Streptococcus anginosus, com maiores valores para os animais WT $(\mathrm{p}<0,05)$. Com relação à Prevotella intermedia, foram encontrados maiores valores para os animais IL-22 KO $(p<0,05)$.

A figura 9 ilustra as espécies que apresentaram diferença estatística significante na comparação entre os dois grupos de animais. 


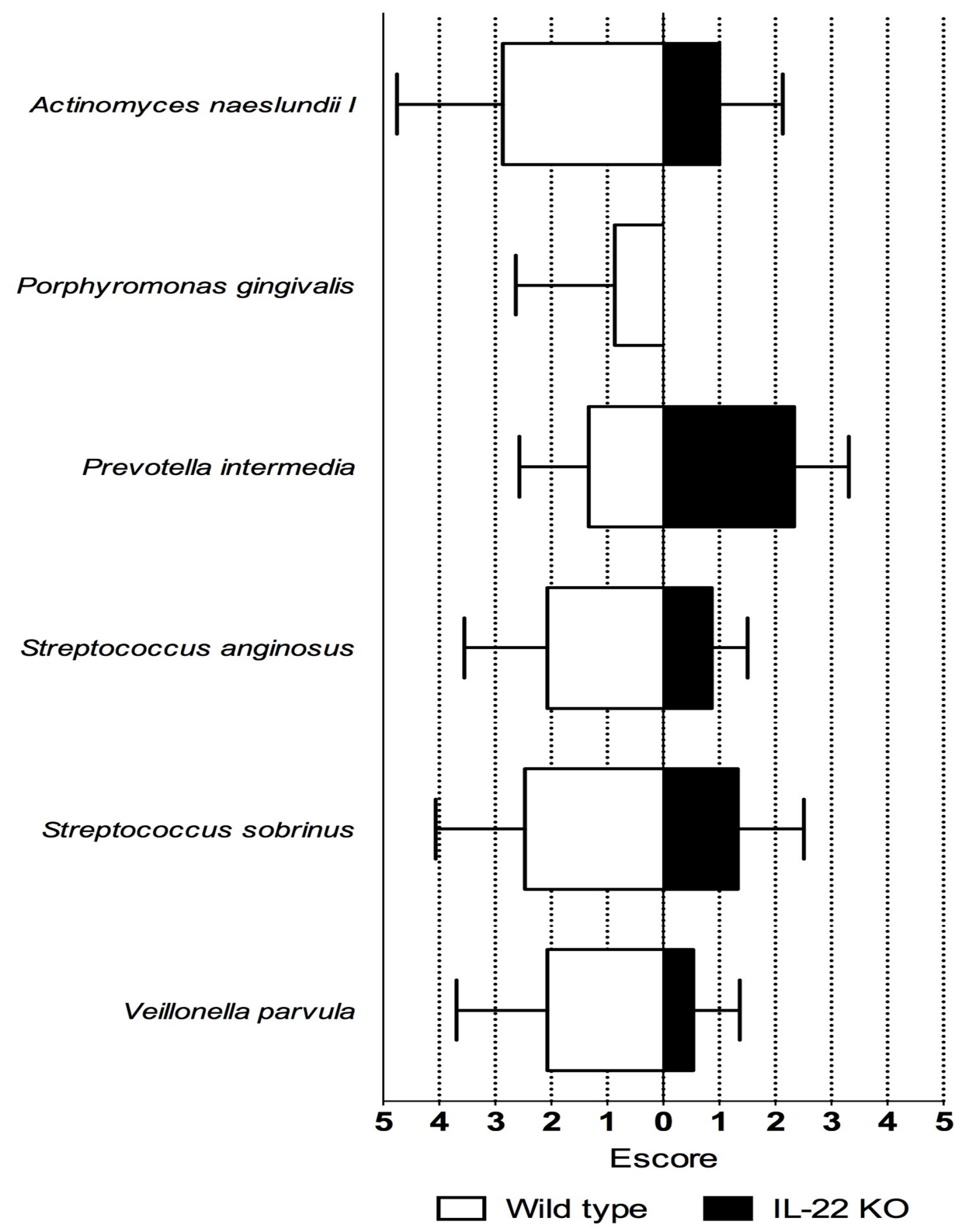

Figura 9. Representação gráfica das espécies bacterianas que se apresentaram em níveis estatisticamente significantes $(p<0,05)$ na cavidade bucal de camundongos. 
A tabela 3 apresenta a relação de sondas de DNA avaliadas na cavidade bucal dos camundongos WT e IL-22 KO e os resultados obtidos.

Tabela 3. Prevalência e quantidade de amostras positivas para as 40 espécies bacterianas avaliadas, nas amostras obtidas da cavidade bucal de camundongos WT e IL-22 KO

\begin{tabular}{|c|c|c|c|}
\hline \multirow{2}{*}{ Espécies bacterianas } & \multicolumn{2}{|c|}{ Prevalência } & \multirow{2}{*}{$\begin{array}{c}\text { Análise } \\
\text { estatística }\end{array}$} \\
\hline & WT & KO & \\
\hline Actinobacillus actinomycetencomytans & $40 \%$ & $26,7 \%$ & \\
\hline Actinomyces gerencseriae & $73,3 \%$ & $80 \%$ & \\
\hline Actinomyces naes/undii & $73,3 \%$ & $53,3 \%$ & $*$ \\
\hline Actinomyces odontolyticus I & $60 \%$ & $46,7 \%$ & \\
\hline Actinomyces oris & $93,3 \%$ & $73,3 \%$ & \\
\hline Campylobater rectus & $60 \%$ & $60 \%$ & \\
\hline Capnocytophaga gingivalis & $53,3 \%$ & $86,6 \%$ & \\
\hline Campylobacter gracilis & $66,7 \%$ & $93,3 \%$ & \\
\hline Capnocytophaga ochracea & $80 \%$ & $93,3 \%$ & \\
\hline Capnocytophaga sputigena & $53,3 \%$ & $80 \%$ & \\
\hline Corynebacterium matruchotti & $46,7 \%$ & $73,3 \%$ & \\
\hline Eubacterium nodatum & $60 \%$ & $80 \%$ & \\
\hline Escherichia coli & $53,3 \%$ & $66,7 \%$ & \\
\hline Enterococcus faecallis & $73,3 \%$ & $60 \%$ & \\
\hline Enterococcus faecium & $60 \%$ & $66,7 \%$ & \\
\hline Fusobacterium nucleatum (sp. nucleatum) & $66,7 \%$ & $80 \%$ & \\
\hline Fusobacterium nucleatum (sp. polymorphum) & $40 \%$ & $40 \%$ & \\
\hline Fusobacterium nucleatum (sp. vincentii) & $73,3 \%$ & $73,3 \%$ & \\
\hline Fusobacterium periodonticum & $13,3 \%$ & $6,7 \%$ & \\
\hline Haemophilus influenzae & $73,3 \%$ & $66,7 \%$ & \\
\hline Helicobacter pylori & $60 \%$ & $66,7 \%$ & \\
\hline Leptotrichia buccalis & $60 \%$ & $80 \%$ & \\
\hline Porphyromonas gingivalis & $26,7 \%$ & 0 & $*$ \\
\hline Prevotella intermedia & $73,3 \%$ & $93,3 \%$ & + \\
\hline Prevotella melaninogenica & $53,3 \%$ & $66,7 \%$ & \\
\hline Propionybacterium acnes & $20 \%$ & $33,3 \%$ & \\
\hline Streptococcus anginosus & $73,3 \%$ & $73,3 \%$ & $*$ \\
\hline Streptococcus constellatus & $53,3 \%$ & $80 \%$ & \\
\hline Streptococcus gordonii & $80 \%$ & $80 \%$ & \\
\hline Streptococcus intermedius & $53,3 \%$ & $80 \%$ & \\
\hline Streptococcus mitis & $60 \%$ & $80 \%$ & \\
\hline Streptococcus mutans & $73,3 \%$ & $60 \%$ & \\
\hline Streptococcus oralis & $66,7 \%$ & $86,6 \%$ & \\
\hline Streptococcus sanguinis & $60 \%$ & $73,3 \%$ & \\
\hline Streptococcus sobrinus & $80 \%$ & $73,3 \%$ & $*$ \\
\hline Streptococcus pneumonia & $46,7 \%$ & $73,3 \%$ & \\
\hline Tannerella forsythia & $80 \%$ & $80 \%$ & \\
\hline Treponema denticola & $86,6 \%$ & $100 \%$ & \\
\hline Treponema Socranskii & $33,3 \%$ & $53,3 \%$ & \\
\hline Veillonella parvula & $73,3 \%$ & $33,3 \%$ & $*$ \\
\hline
\end{tabular}

WT: wild-type

IL-22 KO: knockout

*Diferença estatisticamente significante, com maiores valores para os animais WT.

+Diferença estatisticamente significante, com maiores valores para os animais KO. 


\section{Análise microscópica descritiva do canal radicular e das regiões apical e periapical}

Nos animais WT, 7 dias após a abertura coronária e contaminação do canal radicular, foi possível observar necrose total do tecido pulpar. A superfície cementária era regular e com ausência de áreas de reabsorção. O ligamento periodontal estava suavemente aumentado, com células inflamatórias eventuais, predominantemente mononucleadas. 0 osso alveolar era normal e com osteoblastos na superfície. Aos 21 dias, havia necrose completa do tecido pulpar. O cemento apical apresentava superfície irregular e lacunas vazias ou com restos necróticos. O ligamento periodontal estava amplamente aumentado, com extensas áreas de edema, dissociação fibrilar e células inflamatórias predominantemente mononucleadas espalhadas por toda a região. O osso alveolar apresentava-se desnudo e com áreas de reabsorção na sua superfície. Aos 42 dias, havia necrose pulpar nos três terços do canal radicular. O ligamento periodontal estava severamente ampliado, com presença de infiltrado inflamatório misto denso, localizado tanto próximo quanto à distância do ápice. O osso alveolar apresentava extensas áreas de reabsorção. (Figura 10. A - I).

Nos animais IL-22 KO, aos 7 dias, todos os espécimes apresentavam necrose pulpar. A superfície cementária era regular, sem áreas de reabsorção. O ligamento periodontal estava levemente aumentado, com fibras colágenas remanescentes. Também foi possível observar a presença suave de células inflamatórias mononucleadas em alguns espécimes. O osso alveolar estava normal, com presença de osteoblastos em sua superfície. Aos 21 dias, havia necrose pulpar e a superfície cementária era irregular. O ligamento periodontal estava aumentado, com presença de infiltrado celular inflamatório e perda moderada das fibras colágenas. O osso alveolar apresentava-se desnudo, com algumas áreas de reabsorção. Aos 42 dias havia necrose pulpar, estando a superfície cementária irregular e com presença de áreas de reabsorção. O ligamento periodontal estava ampliado, com presença de edema, infiltrado celular inflamatório e dissociação fibrilar. O osso alveolar apresentava áreas de reabsorção na sua superfície (Figura 11. A - I).

De uma maneira geral, a análise microscópica descritiva permitiu evidenciar que as lesões periapicais dos animais IL-22 KO apresentaram um padrão distinto dos animais WT, com menor infiltrado inflamatório e menor área de reabsorção óssea no período de 42 dias. 

Figura 10. Fotomicrografias representativas dos eventos microscópicos observados após a indução das lesões periapicais em animais wild-type (WT) nos períodos experimentais de 7 dias (A C), 21 dias (D - F) e 42 dias (G - I). Os cortes foram corados com hematoxilina e eosina e observados em microscópico óptico (HE ZEISS 10, 20 e 40x). 


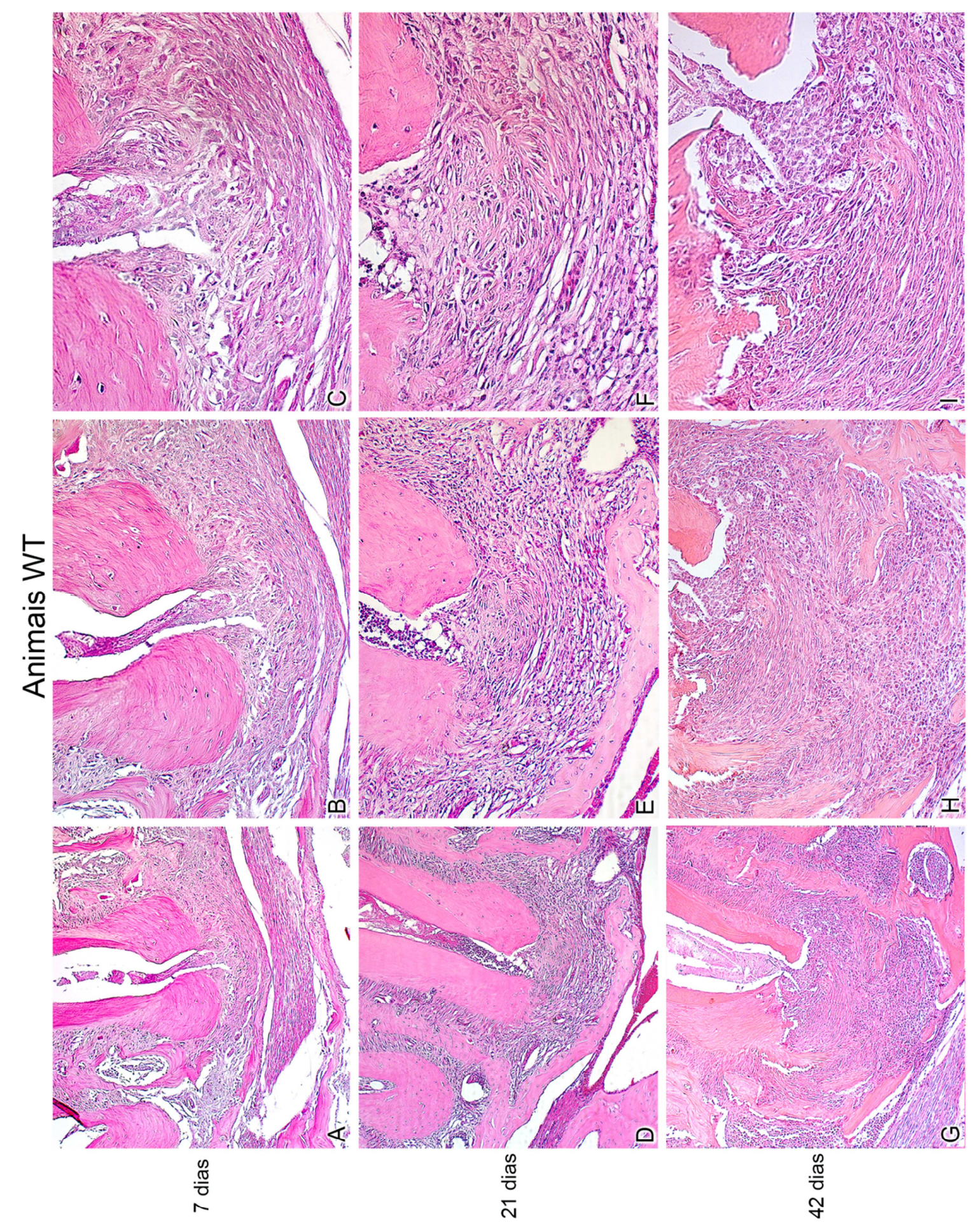




Figura 11. Fotomicrografias representativas dos eventos microscópicos observados após a indução das lesões periapicais em animais knockout para IL-22 (IL-22 KO), nos períodos experimentais de 7 dias $(A-C)$, 21 dias $(D-F)$ e 42 dias $(G-I)$. Os cortes foram corados com hematoxilina e eosina e observados em microscópico óptico (HE ZEISS 10, 20 e 40x). 

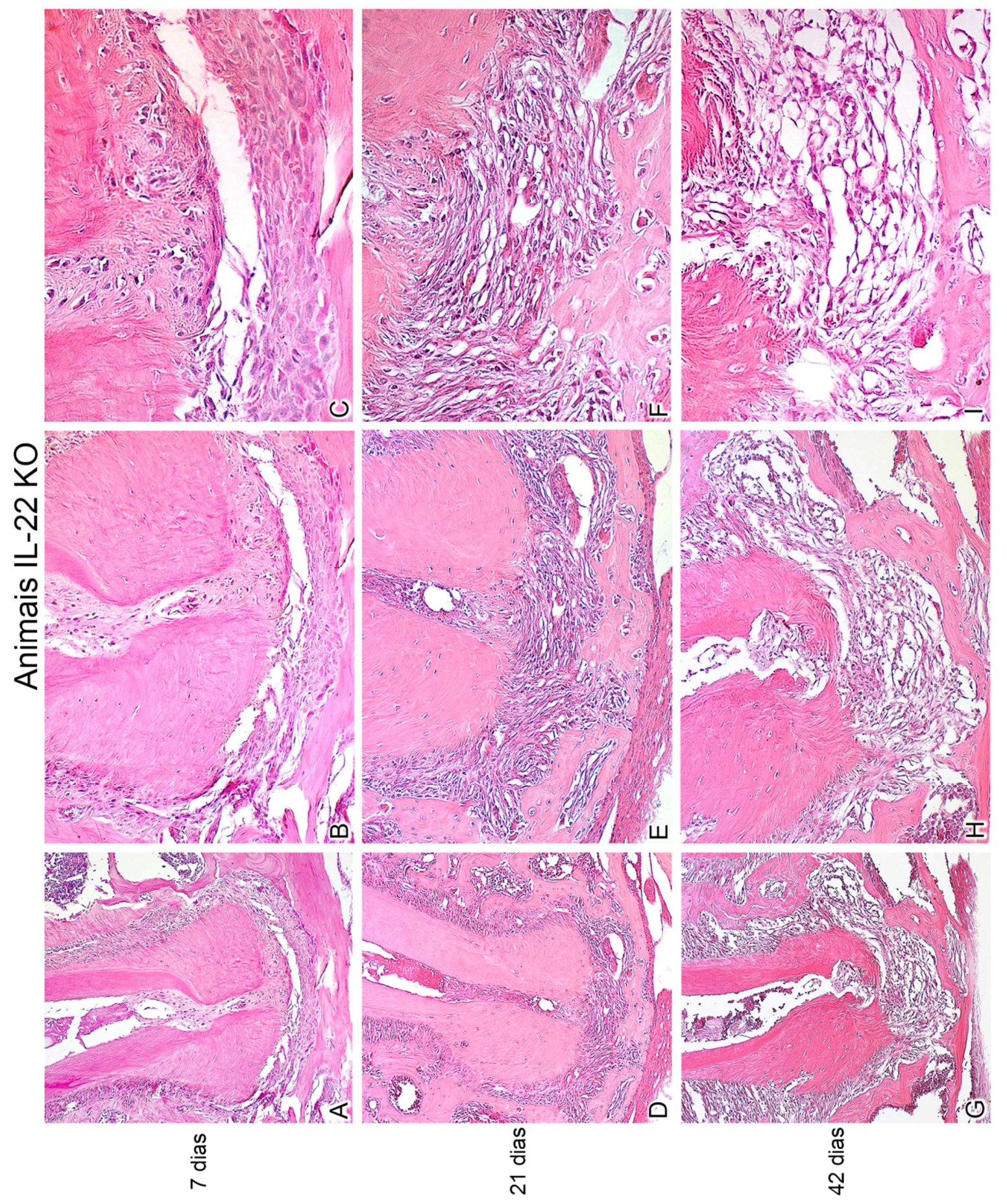



\section{Morfometria em microscopia de fluorescência}

As lâminas submetidas à coloração por hematoxilina e eosina foram observadas em microscópio de fluorescência para mensuração da área das lesões periapicais formadas nos diferentes períodos experimentais.

No grupo dos animais WT pode-se observar um aumento gradativo, em $\mu \mathrm{m}^{2}$, no tamanho das lesões no decorrer dos períodos de 7, 21 e 42 dias após a indução experimental. Os valores médios da área das lesões foram 59.701,38 $\mu \mathrm{m}^{2}, 99.499,86 \mu \mathrm{m}^{2} \mathrm{e}$ $281.772,95 \mu \mathrm{m}^{2}$, respectivamente. A análise estatística realizada por meio do teste one-way ANOVA e pós-teste de Bonferroni demonstrou diferença estatisticamente significante entre os períodos de 7 e 42 dias $(p<0,05)$ e 21 e 42 dias $(p<0,05)$ (Figura 12).

Em relação ao grupo de animais IL-22 KO, os valores médios da área das lesões foram 108.848,41 $\mu^{2}$, 241.169,44 $\mu^{2}$ e 169.597,07 $\mu \mathrm{m}^{2}$, respectivamente, para os períodos de 7, 21 e 42 dias. Neste grupo, observou-se que a progressão das lesões periapicais ao longo dos períodos experimentais não apresentou um padrão tempodependente. Ao contrário, observou-se um aumento no período de 21 dias em relação ao período de 7 dias, com diferença estatisticamente significante $(p<0,05)$ e, em seguida, uma regressão do tamanho das lesões no período de 42 dias, porém sem diferença estatisticamente significante com o período de 7 dias ( $p>0,05)$ (Figura 13). 
Figura 12. Fotomicrografias de cortes microscópicos representativos da mensuração das lesões periapicais em animais wild-type (WT) nos 3 períodos experimentais avaliados. A e B: animais aos 7 dias; C e D: animais aos 21 dias; E e F: animais aos 42 dias. Os cortes foram corados com hematoxilina e eosina e observados em microscópico óptico ( $A, C, E)$ e no modo fluorescente $(B, D, F)$ para análise descritiva da região periapical e para mensuração das lesões periapicais, respectivamente (HE ZEISS 10x). 

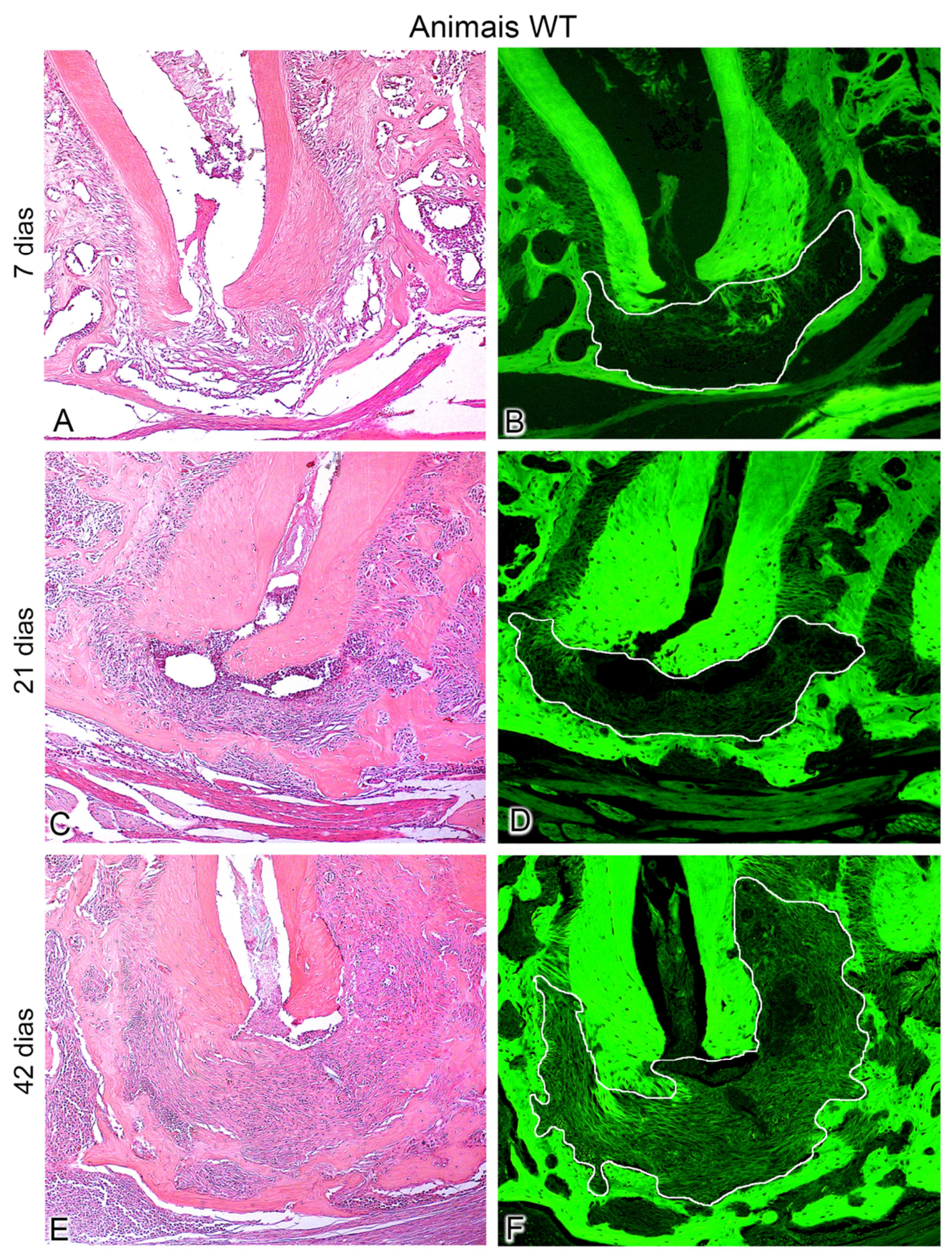


Figura 13. Fotomicrografias de cortes microscópicos representativos da mensuração das lesões periapicais em animais knockout para IL-22 (IL-22 KO), nos 3 períodos experimentais avaliados. A e B: animais aos 7 dias; C e D: animais aos 21 dias; E e F: animais aos 42 dias. Os cortes foram corados com hematoxilina e eosina e observados em microscópico óptico $(A, C, E)$ e no modo fluorescente $(B, D, F)$ para análise descritiva da região periapical e para mensuração das lesões periapicais, respectivamente (HE ZEISS 10x). 

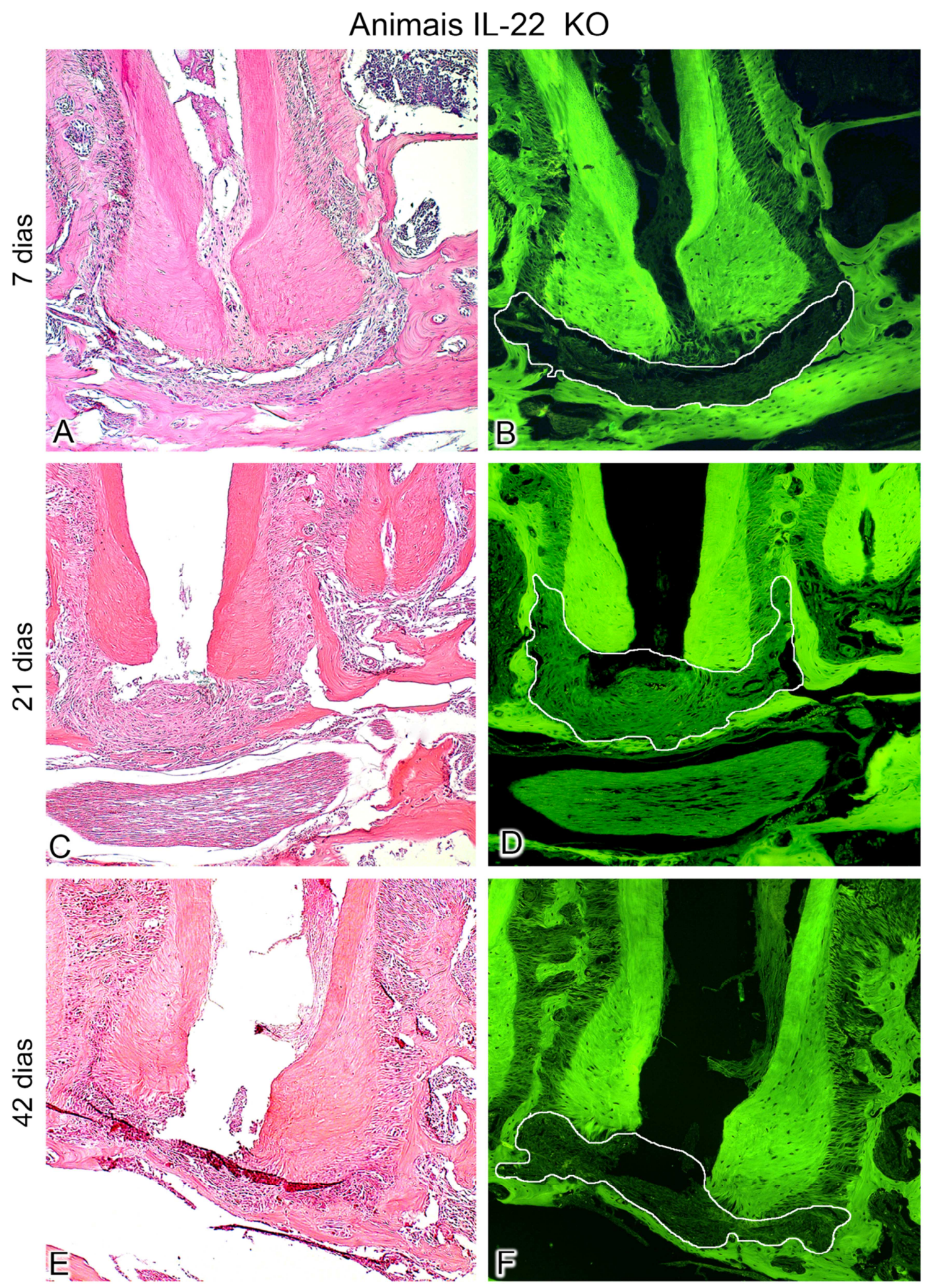

A análise comparativa entre os grupos de animais (WT e IL-22 KO) evidenciou diferença estatisticamente significante nos períodos de 21 e 42 dias $(p<0,05)$, como demonstrado na Figura 14.

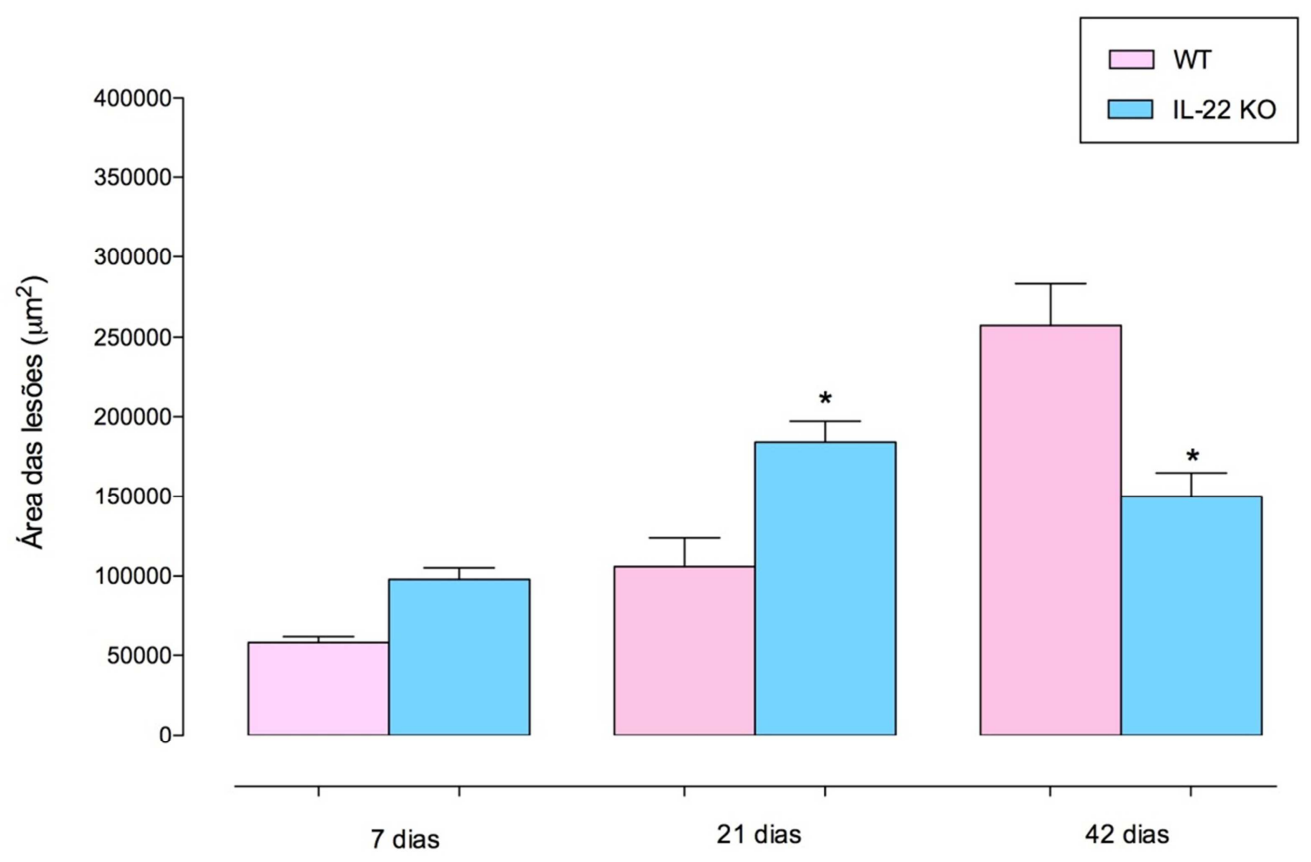

Períodos Experimentais

Figura 14. Representação gráfica dos valores obtidos após a mensuração das lesões periapicais induzidas experimentalmente nos animais wild type e knockout após os períodos experimentais de 7, 21 e 42 dias. $\mathrm{O}$ asterisco representa diferença estatística.

A tabela 4 sumariza os dados obtidos das médias e desvios padrão da mensuração das lesões assim como o valor de p obtido após a realização da análise estatística.

Tabela 4. Média e desvio padrão dos dados obtidos após os períodos experimentais da indução das lesões periapicais nos animais WT e IL-22 KO e resultado da análise estatística.

\begin{tabular}{c|c|c|c|c|c}
\hline \multirow{2}{*}{ Períodos } & \multicolumn{3}{|c|}{ WT } & \multicolumn{2}{c}{ IL-22 KO } \\
\cline { 2 - 5 } & Média & Desvio Padrão & Média & Desvio Padrão & \\
\hline 7 dias & $59.701,38$ & $9.432,88$ & $108.848,41$ & $28.257,48$ & $\mathrm{p}>0,05$ \\
\hline 21 dias & $99.499,86$ & $65.995,94$ & $241.169,44$ & $296.116,03$ & $\mathrm{p}<0,05$ \\
\hline 42 dias & $281.772,95$ & $126.066,62$ & $169.597,07$ & $119.108,77$ & $\mathrm{p}<0,05$ \\
\hline
\end{tabular}

WT $=$ wild-type

$\mathrm{IL}-22 \mathrm{KO}=$ knockout 


\section{Histoenzimologia para a atividade da fosfatase ácida resistente ao tartarato (TRAP)}

A contagem de osteoclastos foi realizada após a aplicação da técnica de histoenzimologia para a marcação da proteína fosfatase ácida resistente ao tartarato (TRAP), em lâminas obtidas dos dentes de camundongos WT e IL-22 KO nos períodos experimentais de 7, 21 e 42 dias após a indução das lesões periapicais (Figura 15).

À semelhança do padrão observado na mensuração das lesões periapicais, no grupo de animais WT, observou-se aumento progressivo no número de osteoclastos, com o decorrer dos períodos. A análise estatística realizada por meio do teste one-way ANOVA e pós-teste de Bonferroni evidenciou diferença significante entre os períodos de 7 e 42 dias e 21 e 42 dias $(p<0,05)$.

No grupo dos animais IL-22 KO, a contagem do número de osteoclastos no decorrer dos períodos experimentais também mostrou um padrão semelhante àquele destacado na mensuração das lesões periapicais, ou seja, com o pico do número dessas células no período de 21 dias e posterior decréscimo no período mais tardio (42 dias). A análise estatística dos dados evidenciou diferença significante somente entre os períodos de 21 e 42 dias $(p<0,05)$.

$\mathrm{Na}$ comparação entre os grupos de animais, pôde-se observar uma semelhança no número de osteoclastos nos períodos de 7 e 21 dias com um discreto aumento no grupo IL-22 KO porém sem diferença estatisticamente significante $(p>0,05)$. Já no período de 42 dias, ocorreu uma diferença significante entre os dois grupos de animais $(p<0,05)$ uma vez que o grupo de animais knockout apresentou drástica redução no número de células osteoclásticas. A Figura 16 ilustra os dados obtidos. 

Figura 15. Fotomicrografias de cortes microscópicos representativos dos animais WT ( $A, B$ e $C$ ) e dos animais IL-22 KO (D, E e F), nos diferentes períodos experimentais, corados por meio da técnica de histoenzimologia para a atividade da fosfatase ácida resistente ao tartarato (TRAP), com o objetivo de identificação e contagem de células multinucleadas (osteoclastos) (HE ZEISS 10x). Em maior aumento (G), células multinucleadas destacadas (HE ZEISS 100x). 

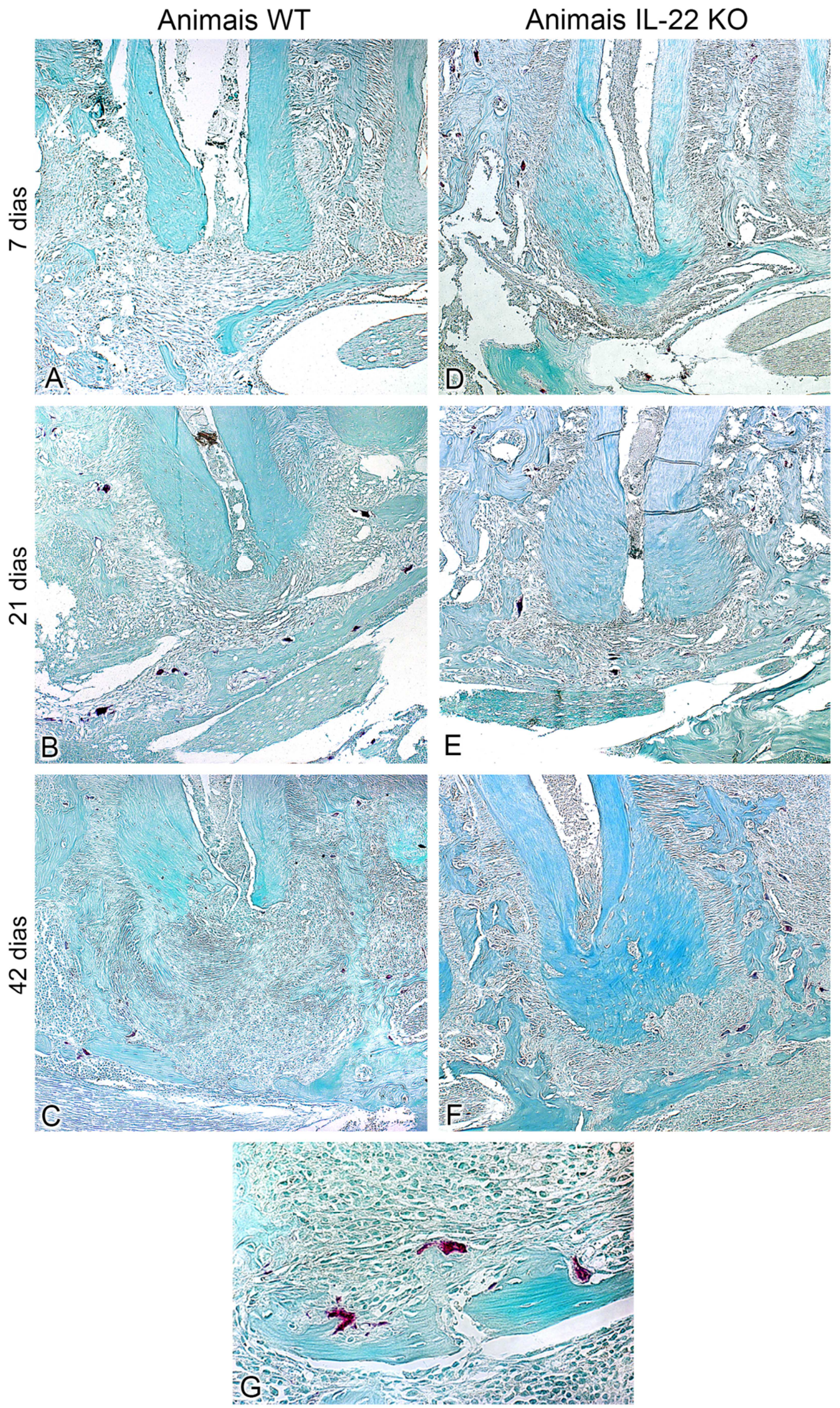



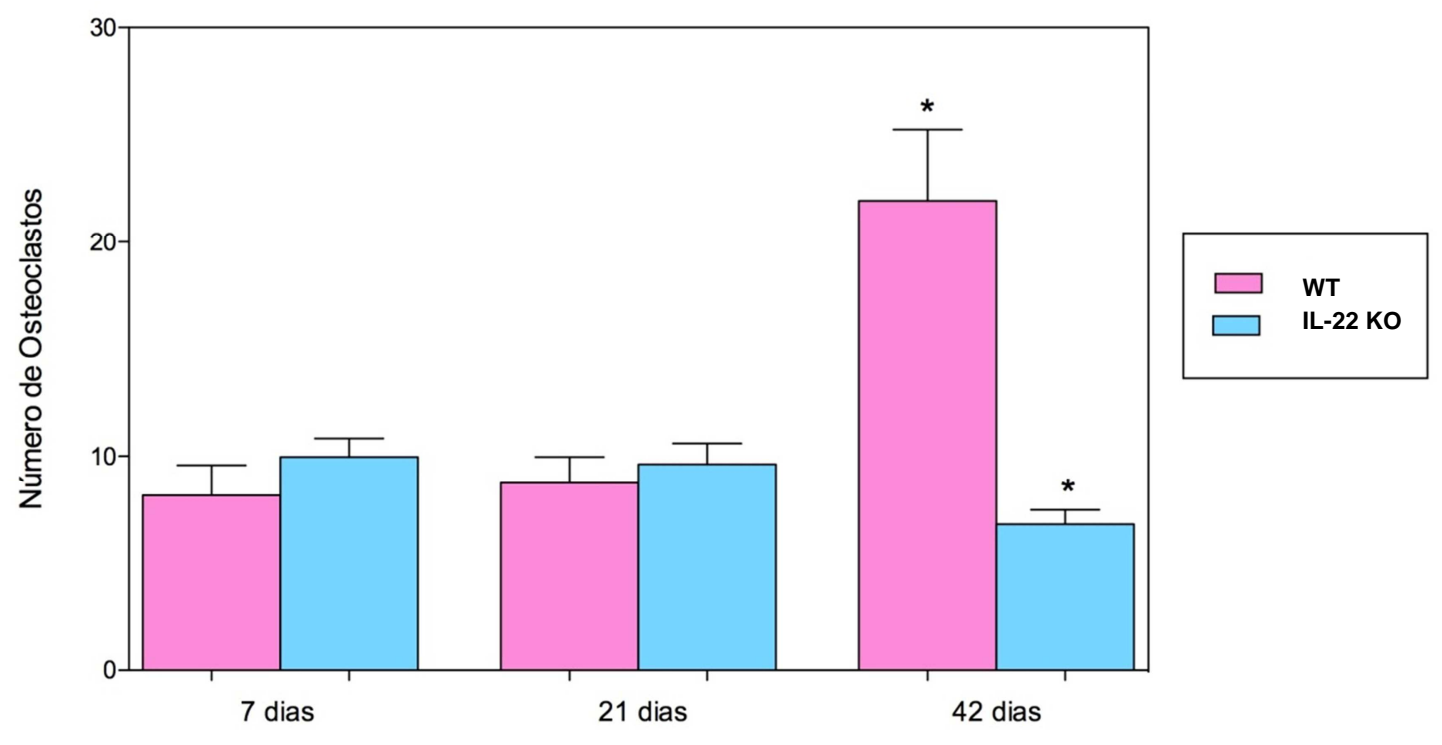

Períodos Experimentais

Figura 16. Representação gráfica da comparação entre os grupos de animais WT e IL-22 KO após a contagem de osteoclastos nas lesões periapicais induzidas experimentalmente, nos períodos de 7, 21 e 42 dias. 0 asterisco representa diferença estatística.

A tabela 5 sumariza os dados obtidos das médias e desvios padrão da mensuração das lesões assim como o valor de $\mathrm{p}$ obtido após a realização a realização da análise estatística.

Tabela 5. Média, desvio padrão e valor de p obtidos após a contagem de osteoclastos nos animais WT e IL-22 KO após os períodos de 7, 21 e 42 dias

\begin{tabular}{l|c|c|c|c|c|}
\hline \multirow{2}{*}{ Períodos } & Média & Desvio Padrão & Média & Desvio Padrão & valor de p \\
\cline { 2 - 6 } & 7,43 & 4,25 & 9,47 & 2,68 & $\mathrm{p}>0,05$ \\
\hline 7 dias & 8,75 & 3,85 & 10,65 & 3,33 & $\mathrm{p}>0,05$ \\
\hline 42 dias & 21,92 & 8,68 & 6,66 & 2,15 & $\mathrm{p}<0,05$ \\
\hline \\
$\begin{array}{l}\text { WT = wild-type } \\
\text { IL-22 KO = knockout }\end{array}$
\end{tabular}

\section{Técnica de Brown \& Brenn}

Todos os espécimes, de ambos os grupos e em todos os períodos de avaliação, foram caracterizados pela presença de bactérias. De uma forma geral, em ambos os grupos de animais, foram encontradas bactérias na coroa do dente e no terço coronário do canal radicular, com micro-organismos frequentemente penetrando nos túbulos 
dentinários e na região interradicular. Para o grupo dos animais WT, os escores 0, 1 e 2 para localização bacteriana não foram registrados. Os escores 3 e 4 foram encontrados em $45,45 \%$ das amostras e o escore 5, em 9,09\%. Já para os animais IL-22 KO, os escores 0 e 1 não foram registrados em nenhum dos cortes avaliados, os escores 2, 3 e 5 foram encontrados em $20 \%$ das lâminas, e o escore 4, em 40\%. A Figura 17 ilustra a presença bacteriana nas diferentes regiões de todo o sistema de canais radiculares dos dentes em ambos os grupos avaliados. 

Figura 17. Fotomicrografias representativas das diferentes áreas do sistema de canais radiculares e região apical e periapical dos animais WT e IL-22 KO, obtidas de cortes microscópicos corados pela técnica de Brown \& Brenn. (A): Micro-organismos presentes ao longo da luz do canal principal e dentina perirradicular (HE ZEISS 4x). B, C e D: maior aumento da figura $A$, evidenciando os terços cervical, médio e apical, respectivamente ( HE ZEISS 40x). Detalhe da intensa contaminação bacteriana ao longo dos túbulos dentinários (E) HE ZEISS 40x. 


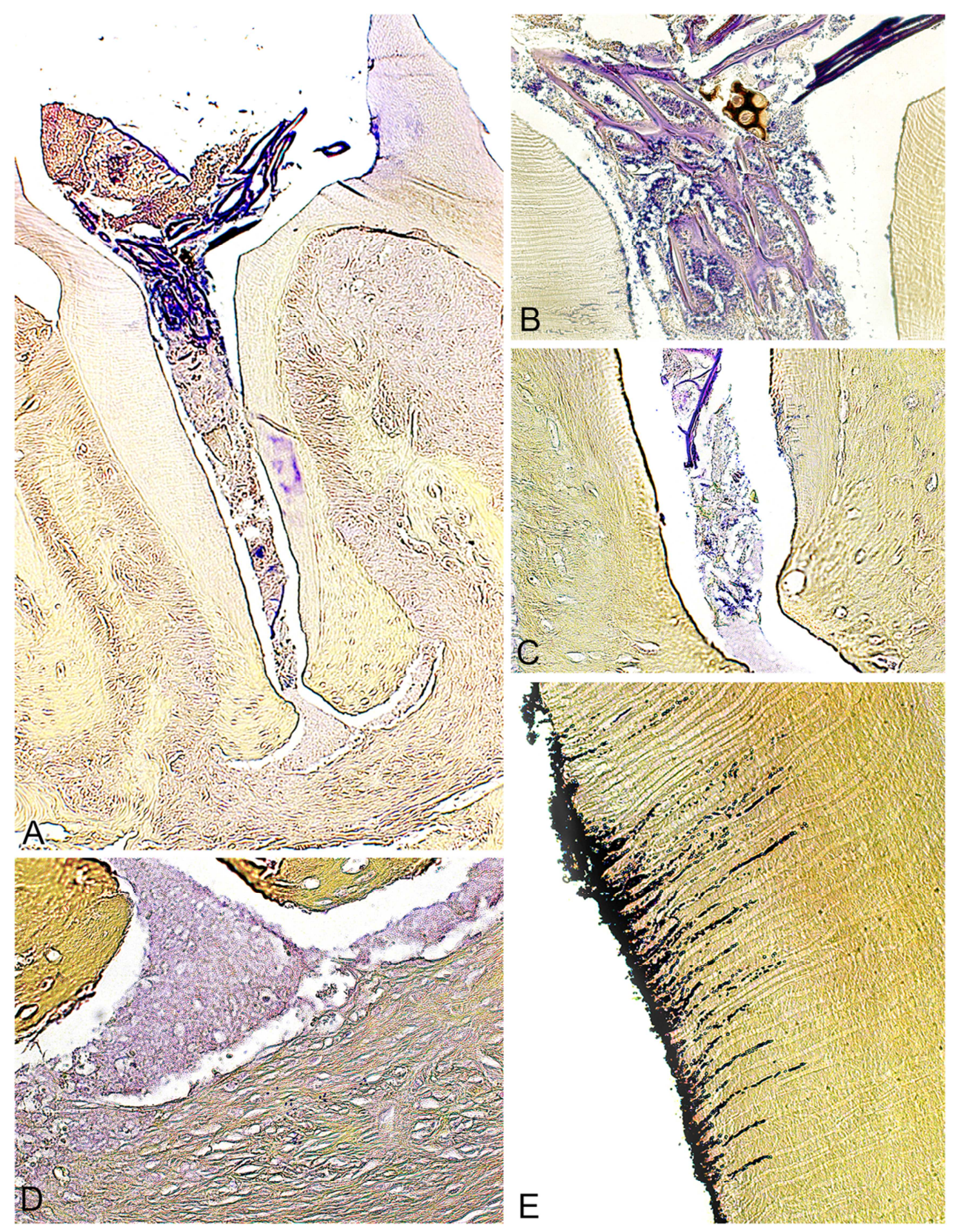





\section{Imunomarcação (Imunohistoquímica)}

No grupo WT, a imunomarcação para RANKL foi detectada aos 7, 21 e 42 dias, principalmente na região do forame apical e no interior da lesão periapical. Imunorreatividade positiva para RANK também foi observada, principalmente ao nível do forame apical e, ocasionalmente, no interior da lesão periapical. A marcação para OPG foi detectada, principalmente, no interior da lesão periapical e em sua periferia. Alguns espécimes também exibiram imunorreatividade positiva para OPG na região do forame apical. (Figura 18).

No grupo dos animais IL-22 KO, marcações para RANK, RANKL e OPG foram observadas nos três períodos experimentais, ocasionalmente no interior do canal radicular, mas, principalmente, na região do forame apical e no interior da lesão periapical (Figura 19). 
Figura 18. Fotomicrografias de cortes microscópicos representativos dos animais WT (A, B e C), corados por meio da técnica de imunohistoquímica para análise qualitativa dos marcadores da osteoclastogênese (RANK, RANKL e OPG) HE ZEISS 10x. 


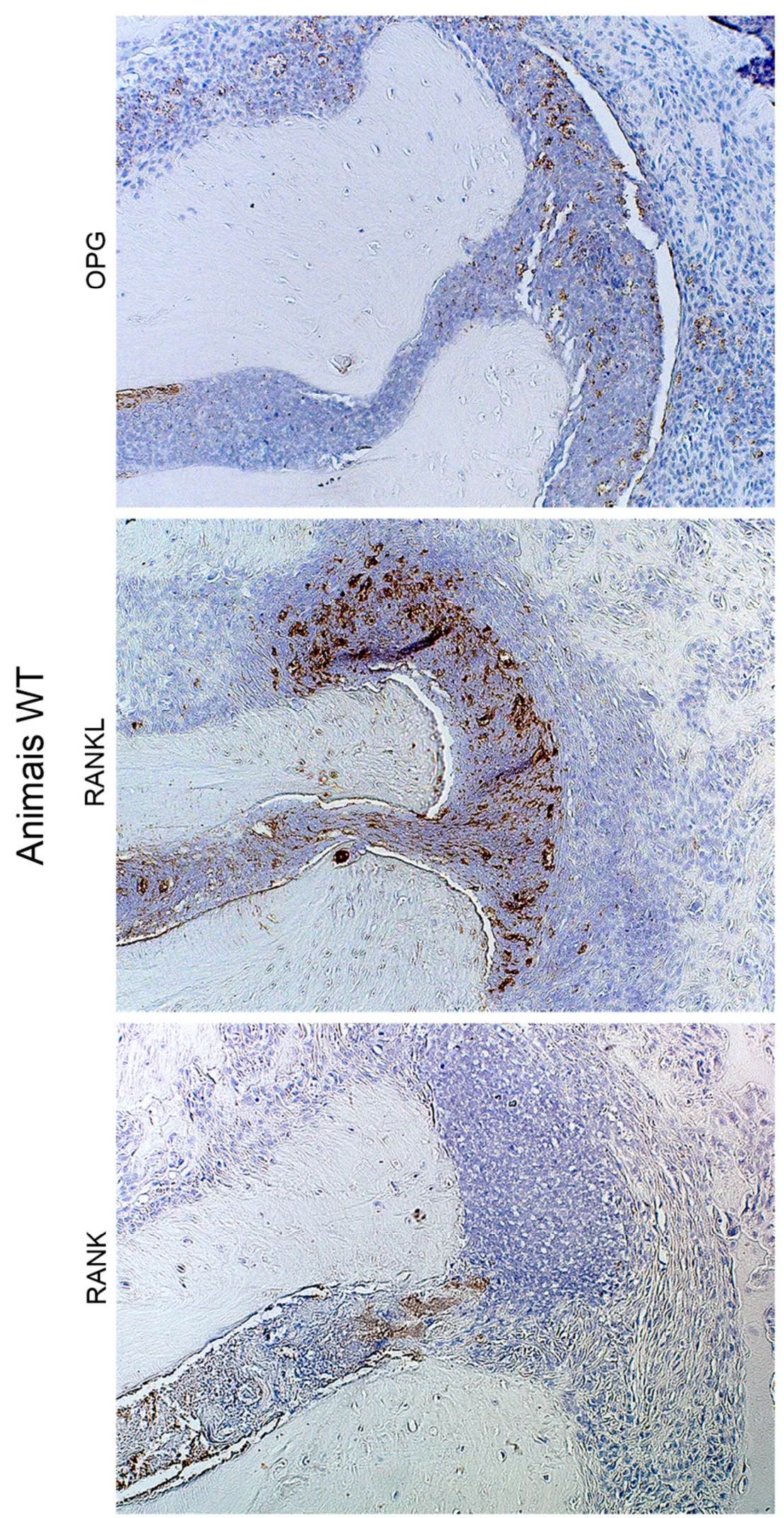




Figura 19. Fotomicrografias de cortes microscópicos representativos dos animais IL-22 KO, nos diferentes períodos experimentais, para análise qualitativa dos marcadores da osteoclastogênese RANK (A e B), RANKL (C e D) e OPG (E e F). Os cortes foram corados por meio da técnica de imunohistoquímica (HE ZEISS 10 e 40x). 
Animais IL-22 KO
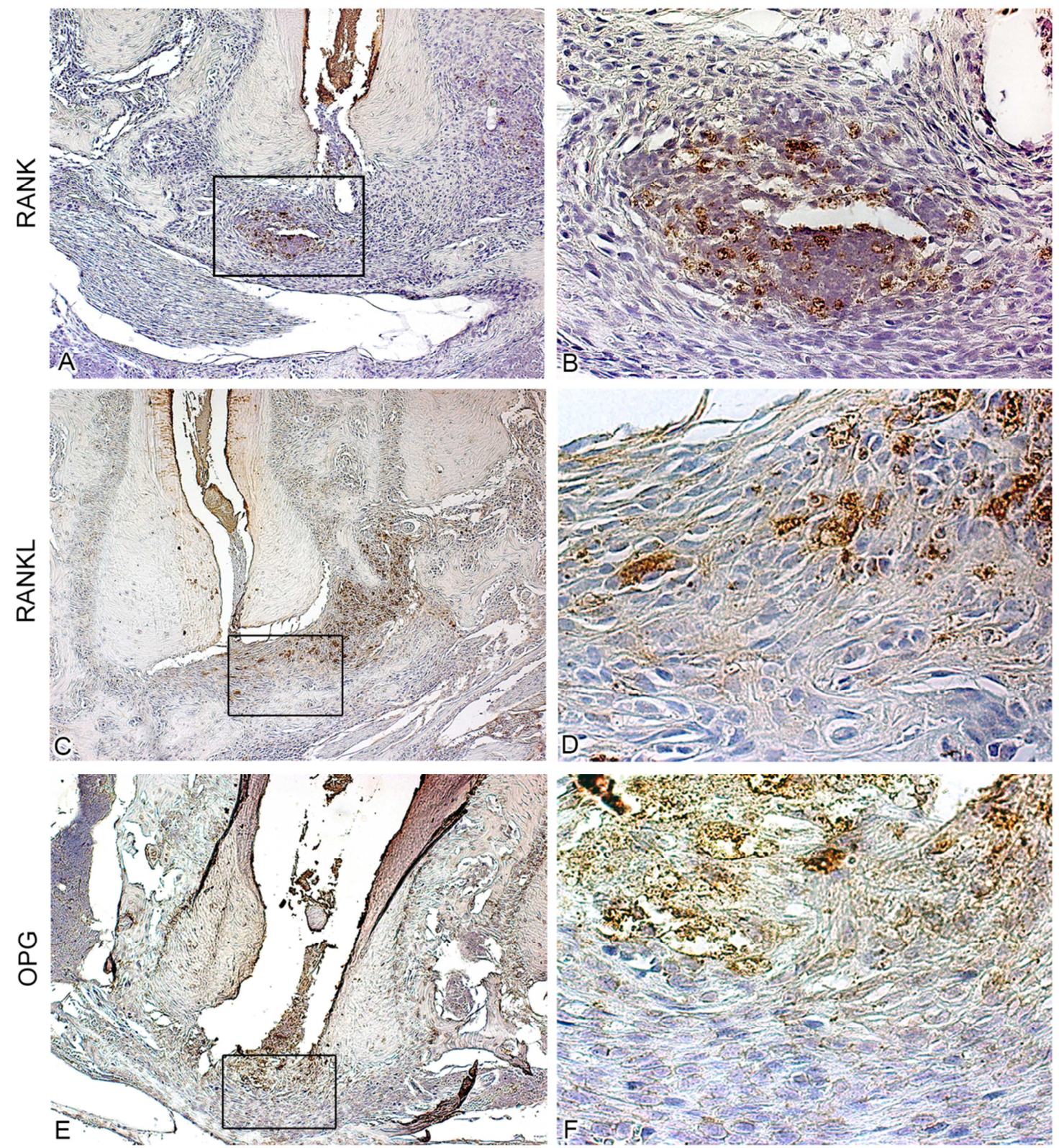

Discussão 

No presente estudo, foi caracterizada a microbiota da cavidade bucal assim como na formação e progressão das lesões periapicais em animais IL-22 KO em comparação com animais WT. Inicialmente, a hipótese era de que os animais knockout apresentariam alteração na sua microbiota bucal e seriam formadas lesões periapicais menores, com progressão equilibrada (tempo-dependente).

De acordo com a metodologia adotada para indução da lesão periapical, a câmara pulpar foi acessada e os canais radiculares permaneceram expostos à cavidade bucal, de modo que a invasão bacteriana no tecido pulpar desencadeasse a formação da lesão (Fouad, 1997; Huang et al., 2001; De Rossi et al., 2008; Silva et al., 2012). Desse modo, a composição da microbiota presente na cavidade bucal dos animais poderia ter influência sobre a composição e o tamanho da lesão periapical.

A partir dos resultados obtidos no presente estudo, observou-se que, tanto nos animais WT como IL-22 KO, a contaminação microbiana da cavidade bucal envolveu a participação de um grande número de espécies, incluindo micro-organismos facultativos, anaeróbios, Gram-positivos e Gram-negativos.

Do total de 40 espécies bacterianas avaliadas, todas estavam presentes na cavidade bucal dos animais WT e 39 estavam presentes nos animais IL-22 KO. Além disso, um maior número de animais do grupo IL-22 KO apresentou contaminação pelas espécies avaliadas. Estes achados podem sugerir, concordando com outros estudos da literatura (Wolk et al., 2004; Aujla et al., 2008), que a IL-22 apresenta participação nos mecanismos de defesa contra micro-organismos, o que pode ter influenciado na formação e progressão das lesões periapicais.

A análise microbiológica permitiu evidenciar que os camundongos WT apresentaram predominância de espécies Gram-positivas, facultativas em relação à tensão de oxigênio, como o $A$. naes/undii, P. gingivalis, $S$. anginosus, S. sobrinus e V. parvula, enquanto que os animais IL-22 KO apresentaram níveis significantemente maiores apenas para a $P$. intermedia, e uma relativa predominância de espécies Gram-negativas anaeróbias.

Poucos estudos avaliaram a contaminação da microbiota bucal de camundongos. Chun et al. (2010) realizaram essa análise, em animais wild-type e knockout para TLR2 por meio da técnica de pirosequenciamento. Os autores relataram que a microbiota dos camundongos parece ser relativamente simples, consistindo basicamente de algumas espécies do gênero estreptococos, estafilococos, lactobacilos, halomonas e enterococos. Além disso, os autores observaram que a microbiota bucal não foi afetada pela deficiência do TLR2 (Chun et al., 2010). 
Contrariamente, os resultados do presente estudo, empregando a técnica de Checkerboard DNA-DNA Hybridization, indicaram que a microbiota bucal de camundongos wild-type e knockout para a IL-22 é bastante complexa, envolvendo a participação de vários tipos de micro-organismos (polimicrobiana).

É importante salientar que a IL-22 pode aumentar a expressão de uma variedade de proteínas em diferentes tipos de tecidos epiteliais sugerindo um papel desta citocina na defesa imune inata, especialmente contra bactérias localizadas nos espaços extracelulares. Em relação a isso, Aujla et al. (2008) mostraram que a IL-22 desempenha um papel importante na infecção pulmonar por $K$. pneumoniae. $O$ tratamento de camundongos infectados, por meio da utilização de anticorpo neutralizador da IL-22 resultou em perda da sua capacidade para controlar a infecção, ao passo que a administração de IL-22 intratraqueal, 12 horas após a infecção, ainda foi capaz de reduzir o número de bactérias dos pulmões. Em contraste, a IL-22 parece apresentar pouco ou nenhum papel no controle de bactérias facultativas localizadas nos espaços intracelulares. Para a defesa contra a infecção sistêmica pela bactéria Gram-positiva Listeria, por exemplo, a IL-22 foi dispensável, uma vez que camundongos deficientes para a IL-22 e IL-17RA desenvolveram respostas imunológicas normais contra esse patógeno (Zenewicz et al., 2007; Aujla et al., 2008). De modo semelhante, a IL-22 não teve nenhuma influência sobre a defesa contra a Francisella tularensis (Lin et al., 2009).

Assim, alguns autores atribuem um papel dual da IL-22 contra microorganismos patogênicos, com atividade antimicrobiana principalmente em tecidos respiratórios, intestinais e em células epidérmicas. Zheng et al., 2008, sugeriram que a IL-22 participa de mecanismos de defesa iniciais contra micro-organismos patogênicos na mucosa intestinal. Wolk et al., 2004, também sugeriram um papel protetor para a IL-22 contra a invasão microbiana, pelo aumento da imunidade inata dos tecidos. Isto também pode ser considerado na avaliação das lesões periapicais nos animais KO, especialmente nos períodos precoces analisados (7 e 21 dias), em que as lesões foram maiores do que nos animais WT.

Em relação aos resultados encontrados de tamanho das lesões periapicais no nosso estudo, se por um lado os animais WT desenvolveram lesões crescentes, de forma tempo-dependente, por outro lado os animais IL-22 KO apresentaram um aumento no tamanho das lesões entre 7 e 21 dias, e diminuição no último período experimental.

Já a análise microscópica descritiva permitiu evidenciar que, em geral, as lesões periapicais dos animais IL-22 KO apresentaram um padrão distinto, com menor quantidade de células inflamatórias e região periapical com predominância de fibras colágenas, embora apresentando dissociação. 
Foi demonstrado, in vitro, que a IL-22 estimulou a osteoclastogênese (Geboes et al., 2009). Da mesma forma, em algumas doenças sistêmicas, esta citocina esteve associada com a indução de diferenciação de osteoclastos (Geboes et al., 2009; Kim et al., 2012). Os resultados do presente estudo são concordantes com esta afirmativa, indicando a participação da IL-22 no processo de osteoclastogênese. Em nosso estudo, a ausência da IL22 nos camundongos IL-22 KO permitiu a observação de lesões periapicais menores, com diminuição considerável do número de osteoclastos. Isto poderia sugerir que, nos tecidos periapicais, esta citocina teria participação no processo de reabsorção óssea.

Por outro lado, outras investigações sugeriram papel distinto para a IL-22. Kato-Kogoe et al. (2012) descreveram que a IL-22 induziu a precipitação de nódulos mineralizados e expressão de genes induzidos por Runx2, MSX2 e osteocalcina em células do ligamento periodontal, sugerindo que a IL-22 pode aumentar a atividade de formação de matriz mineralizada por células do ligamento periodontal.

Nos tecidos periapicais, também foi relatado o envolvimento da IL-22 com um possível papel protetor, uma vez que esta citocina foi encontrada em maiores níveis nas lesões periapicais inativas do que nas ativas, além de correlação da IL-22 com as citocinas IL-10 e TGF- $\beta$ (Aranha et al., 2013).

No entanto, várias questões permanecem obscuras sobre a influência exata de citocinas pró-inflamatórias em lesões periapicais e, além disso, avaliar o papel de cada citocina no complexo contexto da resposta imune é uma tarefa desafiadora.

Assim, os nossos resultados não podem refletir uma explicação direta para 0 papel da IL-22, mas sim os efeitos da sua ausência no complexo contexto de interrelação de citocinas pró-inflamatórias/protetoras envolvidas na resposta imune em lesões periapicais.

É importante considerar, ainda, a superexpressão de citocinas que competem por um mesmo receptor, por exemplo, na tentativa de conter a invasão bacteriana no organismo (Menezes et al., 2008; Hosokawa et al., 2009; Garlet et al., 2010). Sabe-se que a IL-22 exerce seus efeitos biológicos por meio de receptores constituídos por uma cadeia de receptor tipo 1 (R1) e uma cadeia de receptor tipo 2 (R2) e compartilha uma dessas cadeias com a IL-10 (IL-10R2). A ausência dessa citocina poderia causar, por exemplo, a superexpressão da IL-10, interferindo inclusive na expressão de outras citocinas (Wolk e Sabat, 2006).

Nossos resultados não podem ser diretamente comparados com o estudo de Aranha et al. (2013), único trabalho publicado na literatura específica na área de Endodontia, mas poderiam corroborar com vários trabalhos que mostraram um papel dual da IL-22 
dependendo do tecido avaliado, da presença de diferentes tipos celulares e de outras citocinas envolvidas, além da presença de micro-organismos.

Vários estudos destacaram a importância do sistema RANK/RANKL/OPG durante a remodelação óssea (Kawashima et al., 2007; Menezes et al., 2008; Wright et al., 2009; Garlet et al., 2010; Silva et al., 2012). O ativador do receptor do fator nuclear kappa beta (RANKL) é responsável pela indução da reabsorção óssea por meio da estimulação da diferenciação e função de osteclastos. A OPG, também um componente deste sistema, regula o processo de reabsorção óssea evitando a ligação RANKL/RANK (Yasuda et al., 1998). Nossos resultados, após análises qualitativas das lâminas imunocoradas, demonstraram que os três marcadores - RANK, RANKL e OPG - apresentaram marcação com padrão semelhante para os dois grupos de animais, destacando a participação desse sistema no processo de reabsorção óssea nas lesões periapicais.

Além disso, a influência de resposta imune local versus sistêmica também poderia interferir no desenvolvimento da lesão, estimulando especificamente a defesa do hospedeiro. Dessa forma, considerando a resposta imune deficiente em animais knockout, o tamanho das lesões poderia ser influenciado diretamente pela presença ou ausência da IL22.

Desse modo, estudos adicionais são necessários a fim de elucidar os mecanismos moleculares de compensação/estimulação da resposta imune do hospedeiro envolvidos no contexto de formação e progressão das lesões periapicais. 
Conclusão 

Com base na metodologia empregada e nos resultados obtidos, foi possível concluir que a ausência da IL-22 interferiu no padrão de resposta imune e inflamatória, ocasionando diminuição no tamanho das lesões periapicais e no número de osteoclastos no último período experimental avaliado, além de alterar o perfil bacteriano da cavidade bucal. Por outro lado, a ausência desta citocina não interferiu na localização de bactérias na coroa dental e sistema de canais radiculares, assim como no sistema RANK/RANKL/OPG. 

Referências 

1. Aranha AM, Repeke CE, Garlet TP, Vieira AE, Campanelli AP, Trombone AP, Letra A, Silva RM, Garlet GP. Evidence supporting a protective role for th9 and th22 cytokines in human and experimental periapical lesions. J Endod 2013 Jan;39(1):83-7.

2. Aujla SJ, Chan YR, Zheng M, Fei M, Askew DJ, Pociask DA, Reinhart TA, McAllister F, Edeal J, Gaus K, Husain S, Kreindler JL, Dubin PJ, Pilewski JM, Myerburg MM, Mason CA, Iwakura Y, Kolls JK. IL-22 mediates mucosal host defense against Gram-negative bacterial pneumonia. Nat Med 2008;14:275-81.

3. Balto K, Sasaki H, Stashenko P. Interleukin-6 deficiency increases inflammatory bone destruction. Infect Immun 2001;69:744-50.

4. Basak S, Hoffmann A. Crosstalk via the nF-kappaB signaling system. Cytokine Growth Facto Rev 2008;19:187-97.

5. Brand S, Beigel F, Olszak T, Zitzmann K, Eichhorst ST, Otte JM, et al. IL-22 is increased in active Crohn's disease and promotes proinflammatory gene expression and intestinal epithelial cell migration. Am J Physiol Gastrointest Liver Physiol. 2006;290:G827-38.

6. Brown JH, Brenn, L. A method for the differential staining of Gram-positive and Gramnegative bacteria in tissue sections. Bull. Johns Hopkins Hosp 1931; 48:69-73.

7. Cheng F, Guo, Z, Xu H, Yan D, Li Q. Decreased plasma IL22 levels, but not increased IL17 and IL23 levels, correlate with disease activity in patients with systemic lupus erithematosus. Ann Rheum Dis. 2009;68:604-6.

8. Chun J, Kim KY, Lee J, Choi Y. Theranalysis of oral microbial communities of wild-type and toll-like receptor 2-deficient mice using a 454 GS FLX Titanium pyrosequencer. BMC Microbiology 2010;10:101.

9. Chung $\mathrm{Y}$, Yang $\mathrm{X}$, Chang $\mathrm{SH}, \mathrm{Ma} \mathrm{L}$, Tian Q, Dong C. Expression and regulation of IL-22 in the IL-17 producing CD4+ T lymphocytes. Cell Res 2006; 16:902-7.

10. Colic M, Gazivoda D, Vucevic D, Vasilijic S, Rudolf R, Lukic A. Proinflammatory and immunoregulatory mechanisms in periapical lesions. Molecular Immunology 47 (2009) 101-113. 
11. Colonna M. Interleukin-22-producing natural killer cells and lymphoid tissue inducer-like cells in mucosal immunity. Immunity 2009;31:15-23.

12. Cowan J, Pandey S, Filion LG, Angel JB, Kumar A, Cameron DW. Comparison of interferon- $\gamma^{-}$, , interleukin (IL)-17- and IL-22-expressing CD4 T cells, IL-22-expressing granulocytes and proinflammatory cytokines during latent and active tuberculosis infection. Clin Exp Immunol 2012 Feb;167(2):317-29.

13. A: De Rossi A, Rocha LB, Rossi MA. Application of fluorescence microscopy on hematoxylin and eosin-stained sections of healthy and diseased teeth and supporting structures. J Oral Pathol Med 2007;36:377-81.

14. B: De Rossi A, De Rossi M, Rocha LB, da Silva LA, Rossi MA. Morphometric analysis of experimentally induced periapical lesions: radiographic vs histopathological findings. Dentomaxillofac Radiol 2007;36:211-7.

15. De Rossi A, Rocha LB, Rossi MA. Interferon-gamma, interleukin-10, intercellular adhesion molecule- 1 , and chemokine receptor 5 , but not interleukin- 4 , attenuate the development of periapical lesions. J Endod 2008; 34: 31_8.

16. Duhen T, Geiger R, Jarrossay D, Lanzavecchia A, Sallusto F. Production of interleukin 22 but not interleukin 17 by a subset of human skin-homing memory $T$ cells. Nat Immunol. 2009;10:857-63.

17. Dumountier L, Louahed J, Renauld JC. Cloning and characterization of IL-10 related T cell-derived inducible factor (IL-TIF), a novel cytokine structurally related to IL-10 and inducible by IL-9. J Immunol. 2000; 164: 1814-9.

18. Eick S, Pietkiewicz M, Sculean A. Oral microbiota in Swiss adolescents. Clin Oral Investig. 2013 Jan;17(1):79-86.

19. Eyerich S, Eyerich K, Pennino D, Carbone T, Nasorri F, Pallotta S, Cianfarani F, Odorisio $T$, Traidl-Hoffmann $C$, Behrendt $H$, et al. Th22 cells represent a distinct human $T$ cell subset involved in epidermal immunity and remodeling. J Clin Invest 2009;119:35733585. 
20. Fardini Y, Chung P, Dumm R, Joshi N, Han YW. Transmission of diverse oral bacteria to murine placenta: evidence for the oral microbiome as a potential source of intrauterine infection. Infect Immun. 2010 Apr;78(4):1789-96

21. Feinberg AP, Vogelstein B. A technique for radiolabeling DNA restriction endonuclease fragments to high specific activity. Anal Biochem 1983;132:6-13.

22. Feng $D$, Kong $X$, Weng $H$, Park $O$, Wang $H$, Dooley S, Gershwin ME, Gao B. Interleukin22 promotes proliferation of liver stem/progenitor cells in mice and patients with chronic hepatitis B virus infection. Gastroenterology 2012 Jul;143(1):188-98.

23. Fouad AF. IL-1 alpha and TNF-alpha expression in early periapical lesions of normal and immunodeficient mice. J Dent Res 1997; 76: 1548-54.

24. Fujita, H., Nograles, K. E., Kikuchi, T., Gonzalez, J., Carucci, J. A. and Krueger, J. G. Human Langerhans cells induce distinct IL-22-producing CD4+ T cells lacking IL-17 production. Proc. Natl. Acad. Sci. USA 2009;106:21795.

25. Fukada SY, Silva TA, Garlet GP, Rosa AL, da Silva JS, Cunha FQ. Factors involved in the T helper type 1 and type 2 cell commitment and osteoclast regulation in inflammatory apical diseases. Oral Microbiol Immunol 2009; 24: 25_31.

26. Garlet TP, Fukada SY, Saconato IF et al. CCR2 deficiency results in increased osteolysis in experimental periapical lesions in mice. J Endod 2010;36:244-50.

27. Geboes, L., Dumoutier, L., Kelchtermans, H. et al. 2009. Proinflammatory role of the Th17 cytokine interleukin-22 in collagen-induced arthritis in C57BL/6 mice. Arthritis Rheum. 60:390.

28. Gilles J, Carnes D, Dallas M, Holt S, Bonewald L. Oral bone loss is increased in ovariectomized rats. J Endodon 1997;23:419-22.

29. Graves D, Chen C, Douville C, Jiang Y. Interleukin-1 receptor signaling rather than that of tumor necrosis factor is critical in protecting th e host from the severe consequences of a polymicrobe anaerobic infection. Infect Immun 2000; 8: 4746-51. 
30. Graves DT, Oates T, Garlet GP. Review of osteoimmunology and the host response in endodontic and periodontal lesions. Journal of Oral Microbiology 2011;3:5304.

31. Hosokawa Y, Hosokawa I, Ozaki K, Nakae H, Matsuo T. Cytokines differentially regulate CXCL10 production by interferon-gamma-stimulated or tumor necrosis factor-alphastimulated human gingival fibroblasts. J Periodontal Res 2009;44:225-31.

32. Huang GT, Do M, Wingard M, Park JS, Chugal N. Effect of interleukin-6 deficiency on the formation of periapical lesions after pulp exposure in mice. Oral Surg Oral Med Oral Pathol Oral Radiol Endod 2001; 92: 83-8.

33. Jiang Y, Mehta C, Hsu T, Alsulaimani F. Bacteria induce osteoclastogenesis via an osteoblast-independent pathway. Infect Immun 2002;70:3143-8.

34. Kato-Kogoe N, Nishioka T, Kawabe M, Kataoka F, Yamanegi K, Yamada N, Hata M, Yamamoto T, Nakasho K, Urade M, Terada N, Ohyama H. The promotional effect of IL22 on mineralization activity of periodontal ligament cells. Cytokine 2012;59:41-8.

35. Kawashima N, Suzuki N, Yang G, Ohi C, Okuhara S, Nakano-Kawanishi H, Suda H. Kinetics of RANKL, RANK and OPG expressions in experimentally induced rat periapical lesions. Oral Surg Oral Med Oral Pathol Oral Radiol Endod 2007 May;103(5):707-11.

36. Kawashima N, Stashenko P. Expression of bone-resorptive and regulatory cytokines in murine periapical inflammation. Arch Oral Biol 1999;44:55-66.

37. Khocht A, Yaskell T, Janal M, Turner BF, Rams TE, Haffajee AD, Socransky SS. Subgingival microbiota in adult Down syndrome periodontitis. J Periodontal Res. 2012 Aug;47(4):500-7.

38. Kim KW, Kim HR, Park JY, Park JS, Oh HJ, Woo YJ, Park MK, Cho ML, Lee SH. Arthritis Rheum 2012;64(4):1015-23.

39. Kotenko SV, Izotova LS, Mirochnitchenko OV, Esterova E, Dickensheets $H$, Donnelly RP, et al. Identification of the functional interleukin-22 (IL-22) receptor complex: the IL- 
10R2 chain (IL-10Rbeta) is a common chain of both the IL-10 and IL-22 (IL-10-related T cell-derived inducible factor, IL-TIF) receptor complexes. J Biol Chem. 2001; 276:272532.

40. Liang SC, Tan XY, Luxenberg DP, Karim R, Dunussi-Joannopoulos K, Collins M, et al. Interleukin (IL)-22 and IL-17 are co-expressed by Th17 cells and cooperatively enhance expression of antimicrobial peptides. J Exp Med 2006; 203:2271-9.

41. Liang SC et al. IL-22 induces an acute-phase response. J Immunol. 2010:5531-38.

42. Lin Y, Ritchea S, Logar A, Slight S, Messmer M, Rangel-Moreno J, Guglani L, Alcorn JF, Strawbridge H, Park SM, Onishi R, Nyugen N, Walter MJ, Pociask D, Randall TD, Gaffen $\mathrm{SL}$, Iwakura $\mathrm{Y}$, Kolls JK, Khader SA. Interleukin-17 is required for $\mathrm{T}$ helper 1 cell immunity and host resistance to the intracellular pathogen Francisella tularensis. Immunity 2009 Nov 20;31(5):799-810.

43. Martin B, Hirota K, Cua DJ, Stockinger B, Veldhoen M. Interleukin-17-producing gammadelta $\mathrm{T}$ cells selectively expand in response to pathogen products and environmental signals. Immunity 2009 Aug 21;31(2):321-30.

44. McNicholas S, Torabinejad M, Blankenship J, Bakland L. The concentration of prostaglandin E2 in human periradicular lesions. J Endod 1991; 17: 97_100.

45. Menezes R, Garlet TP, Trombone AP, et al. The potential role of supressors of cytokine signaling in the attenuation of inflammatory reaction and alveolar bone loss associated with apical periodontitis. J Endod 2008;34:1480-4.

46. Moraes SR, Siqueira Júnior JF, Colombo AP, Rôças IN, Ferreira MCS, Domingues RMCP. Comparison of the effectiveness of bacterial culture, 16S rDNA directed polymerase chain reaction, and checkerboard DNA-DNA hybridization for detection of Fusobacterium nucleatum in endodontic infections. J. Endod 2002;28:86-9.

47. Nair PN. Pathogenesis of apical periodontitis and the causes of endodontic failures. Crit Rev Oral Biol Med 2004; 15: 348-81.

48. Nakagome K, Imamura M, Kawahata K, Harada H, Okunishi K, Matsumoto T, Sasaki O, Tanaka R, Kano MR, Chang H, Hanawa H, Miyazaki J, Yamamoto K, Dohi M. High expression of IL-22 suppresses antigen-induced immune responses and eosinophilic 
airway inflammation via an IL-10-associated mechanism. J Immunol. 2011 Nov 15;187(10):5077-89.

49. Nelson-Filho P, Carpio-Horta KO, Andrucioli MC, Feres M, Bezerra da Silva RA, Garcia Paula-Silva FW, Romano FL. Molecular detection of Aggregatibacter actinomycetemcomitans on metallic brackets by the checkerboard DNA-DNA hybridization technique. Am J Orthod Dentofacial Orthop. 2012 Oct;142(4):481-6.

50. Nickoloff BJ. Cracking the cytokine code in psoriasis. Nat Med. 2007;13:242-4.

51. Nograles KE, Zaba LC, Shemer A, Fuentes-Duculan J, Cardinale I, Kikuchi T, Ramon M, Bergman R, Krueger JG, Guttman-Yassky E. IL-22-producing "T22" T cells account for upregulated IL-22 in atopic dermatitis despite reduced IL-17-producing Th17 T cells. J Allergy Clin Immunol 2009;123:1244-1252 e1242.

52. Sabat R, Grütz G, Warszawska K, Kirsch S, Witte E, Wolk K, et al. Biology of interleukin10. Cytokine Growth Factor Rev 2010;21:331-44.

53. Sasaki H, Balto K, Kawashima N, et al. Gamma interferon (IFN-gamma) and IFNgammainducing cytokines interleukin-12 (IL-12) and IL-18 do not augment infection-stimulated bone resorption in vivo. Clin Diagn Lab Immunol 2004;11:106 -10.

54. Satoh-Takayama N, Vosshenrich CA, Lesjean-Pottier S, Sawa S, Lochner M, Rattis F, Mention JJ, Thiam K, Cerf-Bensussan N, Mandelboim O, et al. Microbial flora drives interleukin 22 production in intestinal NKp46+ cells that provide innate mucosal immune defense. Immunity 2008;29:958-970.

55. Siegemund S, Schutze N, Schulz S, Wolk K, Nasilowska K, Straubinger RK, Sabat R, Alber G. Differential IL-23 requirement for IL-22 and IL-17A production during innate immunity against salmonella enterica serovar enteritidis. Int Immunol 2009;21:555-565.

56. Silva RAB, Ferreira PDF, De Rossi A, Nelson-Filho P, Silva LAB. Toll-like Receptor 2 Knockout Mice Showed Increased Periapical Lesion Size and Osteoclast Number. J Endod 2012;38:803-813. 
57. Siqueira Júnior JF, Rôças IN, Favieri A, Santos KRN. Detection of Treponema denticola in endodontic infections by $16 \mathrm{~S}$ rRNA gene directed polymerase chain reaction. Oral Microbiol Immunol 2000;15: 335-7.

58. Smith GL, Sansone C, Socransky SS. Comparison of two methods for the small-scale extraction of DNA from subgingival microorganisms. Oral Microbiol Immunol. $1989 ; 4: 135-40$.

59. Socransky SS, Smith C, Martin L, Paster BJ, Dewhirst FE, Levin AE. "Checkerboard" DNADNA hybridization. Biotechniques 1994;17:788-92.

60. Sonnenberg GF, Fouser LA, Artis D. Border patrol: regulation of immunity, inflammation and tissue homeostasis at barrier surfaces by IL-22. Nat Immunol 2011;12(5):383-390.

61. Stange J, Hepworth MR, Rausch S, Zajic L, Kühl AA, Uyttenhove C, Renauld JC, Hartmann S, Lucius R. IL-22 mediates host defense against an intestinal intracellular parasite in the absence of IFN- $\gamma$ at the cost of Th17-driven immunopathology. J Immunol 2012 Mar 1;188(5):2410-8.

62. Stashenko P, Yu SM, Wang CY. Kinetics of immune cell and bone resorptive responses to endodontic infections. J Endod 1992; 18: 422_6.

63. Stashenko P, Wang CY, Tani-Ishii N, Yu SM. Pathogenesis of induced rat periapical lesions. Oral Surg Oral Med Oral Pathol 1994; 78: 494-502.

64. Stashenko P,Wang C, Riley E,Wu Y, Ostroff G, Niederman R. Reduction of infectionstimulated peripical bone resorption by the biological response modifier PGG glucan. J Dent Res 1995; 74: 323-30.

65. Sutton CE, Lalor SJ, Sweeney CM, Brereton CF, Lavelle EC, Mills KH. Interleukin-1 and IL-23 induce innate IL-17 production from gammadelta $T$ cells, amplifying Th17 responses and autoimmunity. Immunity 2009;31:331-341.

66. Takahashi K, Hirose K, Kawashima S, Niwa Y, Wakashin H, Iwata A, Tokoyoda K, Renauld JC, Iwamoto I, Nakayama T, Nakajima H. IL-22 attenuates IL-25 production by lung epithelial cells and inhibits antigen-induced eosinophilic airway inflammation. J Allergy Clin Immunol 2011 Nov;128(5):1067-76. 
67. Tani N, Kuchiba K, Osada T, Watanabe Y, Umemoto T. Effect of T-cell deficiency on the formation of periapical lesions in mice: histological comparison between periapical lesion formation in BALB/C and BALB/c nu/nu mice. J Endod 1995;21: 195-199.

68. Tani-Ishii N, Wang CY, Stashenko P. Immunolocalization of bone-resorptive cytokines in rat pulp and periapical lesions following surgical pulp exposure. Oral Microbiol Immunol $1995 ; 10: 213-9$.

69. Teles R, Wang CY, Stashenko P. Increased susceptibility of RAG-2 SCID mice to dissemination of endodontic infections.Infect Immun 1997;65:3781-7.

70. Trudel L, St-Amand L, Bareil M, Cardinal P, Lavoie MC. Bacteriology of the oral cavity of BALB/c mice. Can J Microbiol. 1986 Aug;32(8):673-8.

71. Van Belle AB, de Heusch M, Lemaire MM, Hendrickx E, Warnier G, Dunussi-Joannopoulos K, Fouser LA, Renauld JC, Dumoutier L. IL-22 is required for imiquimod-induced psoriasiform skin inflammation in mice. J Immunol 2012 Jan 1;188(1):462-9.

72. Wallstrom JB, Torabinejad M, Kettering J, McMillan P. Role of T cells in the pathogenesis of periapical lesions. A preliminary report. Oral Surg Oral Med Oral Pathol 1993;76:213-8.

73. Wang C, Stashenko P. The role of interleukin-1 alpha in the pathogenesis of periapical bone destruction in a rat model system. Oral Microbiol Immunol 1993; 8: 50-6.

74. Wolk K, Kunz S, Asadullah K, Sabat R. Cutting edge: Immune cells as sources and targets of the IL-10 family members? J Immunol 2002;168:5397-5402.

75. Wolk K, Kunz S, Witte E, Friedrich M, Asadullah K, Sabat R. IL-22 increases the innate immunity of tissues. Immunity 2004;21(2):241-254.

76. A: Wolk K, Sabat R. Interleukin-22: a novel T- and NK-cell derived cytokine that regulates the biology of tissue cells. Cytokine Growth Factor Rev 2006;17:367-80.

77. B: Wolk K, Witte E, Wallace E, Docke WD, Kunz S, Asadullah K, et al. IL-22 regulates the expression of genes responsible for antimicrobial defense, cellular differentiation, and mobility in keratinocytes: a potential role in psoriasis. Eur J Immunol 2006;36:1309-23. 
78. Wolk K, Witte E, Hoffmann U, Doecke WD, Endesfelder S, Asadullah K, Sterry W, Volk HD, Wittig BM, Sabat R. IL- 22 induces lipopolysaccharide-binding protein in hepatocytes: a potential systemic role of IL-22 in Crohn's disease. J Immunol 2007;178(9):5973-5981.

79. Wright HL, McCarthy HS, Middleton J, Marshall MJ. RANK, RANKL and osteoprotegerin in bone biology and disease. Curr Rev Musculoskelet Med 2009;2:56-64.

80. Xie MH, Aggarwal S, Ho WH, Foster J, Zhang Z, Stinson J, et al. Interleukin (IL)-22, a novel human cytokine that signals throught the interferon receptor-related proteins CRF2-4 and IL-22R. J Biol Chem. 2000; 275:31335-9.

81. Xu W, Presnell SR, Parrish-Novak J, et al. A soluble class II cytokine receptor, IL-22RA2, is a naturally occurring IL-22 antagonist. Proc Natl Acad Sci USA 2001;98:9511-6.

82. Yasuda H, Shima N, Nakagawa N, Yamaguchi K, Kinosaki M, Mochizuki S, Tomoyasu A, Yano K, Goto M, Murakami A, Tsuda E, Morinaga T, Higashio K, Udagawa N, Takahashi $\mathrm{N}$, Suda T. Osteoclast differentiation factor is a ligand for osteoprotegerin/osteoclastogenesis-inhibitory factor and is identical to TRANCE/RANKL. Proc Natl Acad Sci U S A 1998 Mar 31;95(7):3597-602.

83. Zenewicz LA, Flavell RA. Recent advances in IL-22 biology. International Immunology, 2011; 23: No. 3, pp. 159-163.

84. Zenewicz LA, Yancopoulos GD, Valenzuela DM, Murphy AJ, Karow M, Flavell RA.Interleukin-22 but not interleukin-17 provides protection to hepatocytes during acute liver inflammation. Immunity 2007 Oct;27(4):647-59.

85. Zheng Y, Valdez PA, Danilenko DM, Hu Y, Sa SM, Gong Q, Abbas AR, Modrusan Z, Ghilardi N, de Sauvage FJ, et al. Interleukin-22 mediates early host defense against attaching and effacing bacterial pathogens. Nat Med 2008;14:282-28. 

Anexo 



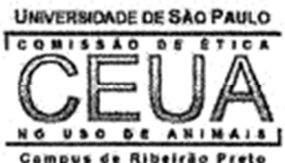

\author{
UNIVERSIDADE DE SÃO PAULO \\ Campus de Ribeirão Preto \\ Comissão de Ética no Uso de Animais
}

\title{
C E R T I F I C A D O
}

Certificamos que o trabalho (Protocolo $n^{\circ}$ 11.1.1403.53.5), intitulado "Estudo da Gênese e Progressão de Lesões Periapicais Induzidas Experimentalmente em Dentes de Camundongos Wild-type e knockout', de autoria de Katharina Morant Holanda de Oliveira, e de Raquel Antunes Bezerra da Silva por estar de acordo com os Princípios Éticos na Experimentação Animal adotado pela Comissão de Ética no Uso de Animais (CEUA) do Campus de Ribeirão Preto - USP foi aprovado em reunião da CEUA de 07.03.2012.

This is to certify that the work (Protocol number 11.1.1403.53.5), entitled: "Estudọ da Gênese e Progressão de Lesões Periapicais Induzidas Experimentalmente em Dentes de Camundongos Wild-type e knockout', by Katharina Morant Holanda de Oliveira and Raquel Antunes Bezerra da Silva, is in accordance with the Ethic Principles in Animal Experimentation adopted by Ethic Commission for the Use of Animals (CEUA) of the Campus of Ribeiräo Preto - USP, and was approved in the meeting, March 07, 2012.

Ribeirăo Preto, 27 de março de 2012.

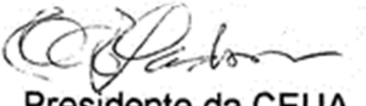

Presidente da CEUA

Profa.Dra. Cláudia Maria Padovan

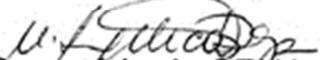

Secretaria da CEUA

Maria Angélica Depiro

Av. Bandeirantes, 3900 - CEP 14040-900 - Ribeirão Preto - São Paulo Fone: (16) 36024469 - Fax. (16) 36337964 